\title{
DESAFIOS À ELABORAÇÃO CURRICULAR PARA A EDUCAÇÃO ESCOLAR INDÍGENA: REFLEXÕES E ALTERNATIVAS DE ENFRENTAMENTO DOS POVOS KARAJÁ XAMBIOÁ E GUARANI
}

\author{
ANDRÉ MARQUES DO NASCIMENTO ${ }^{1}$
}

$U F G$

\begin{abstract}
RESUMO: As experiências pedagógicas e epistemológicas implementadas no curso de Licenciatura Intercultural da Universidade Federal de Goiás têm colaborado sobremaneira com o desvelamento de aspectos importantes concernentes à educação escolar indígena inserida na contemporaneidade das relações interculturais em que os povos indígenas brasileiros interatuam e, cada vez mais, tornam-se seus protagonistas. Muitos, no entanto, ainda são os desafios enfrentados na consecução da tão aclamada educação escolar específica, diferenciada e em coerência com os projetos de vida e de sustentabilidades dos povos indígenas, direito garantido constitucionalmente no Brasil. No que concerne precisamente à gestão pedagógica da educação escolar, a elaboração e a implementação do currículo é, sem dúvida, uma das principais dimensões destes desafios. Neste contexto, propõe-se neste trabalho a apresentação das bases para a construção das matrizes curriculares a partir da experiência de Estágio Pedagógico de professores indígenas karajá xambioá e guarani, destacando-se a dimensão contextual dos conhecimentos locais desde uma perspectiva intercultural $e$ transdisciplinar.
\end{abstract}

PALAVRAS-CHAVE: Educação escolar indígena; Currículo; Terra Indígena Karajá Xambioá.

\begin{abstract}
Pedagogical and epistemological experiences developed in the undergraduate course of Licenciatura Intercultural at Universidade Federal de Goiás have contributed to the unveiling of important aspects concerning indigenous school education inserted in contemporary intercultural relations in which Brazilian Indigenous people interact and increasingly become their protagonists. However, many are still the challenges faced in achieving the so acclaimed especific, differentiated and consistent with the Indigenous peoples' life projects and sustainability school education, a constitutionally guaranteed right in Brazil. Concerning specifically to the pedagogical management, curriculum development and implementation certainly is one of the main dimensions of these challenges. Thus, this paper proposes a presentation of the foundations for the construction of curriculum matrices form the experiences developed during Karajá Xambioá and Guarani's teacher trainning, highlighting the contextual dimension of local knowledge form an intercultural and transdisciplinary perspective.
\end{abstract}

KEYWORDS: Indigenous school education; Curriculum; Karajá Xambioá Indigenous Land.

\footnotetext{
${ }^{1}$ Doutor em Letras e Linguística pela Universidade Federal de Goiás; professor Adjunto I de Português Intercultural no curso de Licenciatura Intercultural para Formação Superior de Professores e Professoras Indígenas desta universidade; orienta atividades de pesquisa e Estágio Pedagógico dos professores Karajá Xambioá e Guarani. E-mail: marquesandre@yahoo.com.br .
}

Espaço Ameríndio, Porto Alegre, v. 7, n. 1, p. 95-145, jan./jun. 2013. 


\section{A Licenciatura Intercultural da Universidade Federal de Goiás: breve panorama}

Como desdobramento da demanda dos povos indígenas brasileiros pelo cumprimento do direito constitucional a uma educação escolar específica, diferenciada e que garanta a "utilização de suas línguas maternas e processos próprios de aprendizagem" (BRASIL, 1988, p. 104), a formação superior específica de professores e professoras indígenas, há algum tempo, figura como mais uma importante demanda destes povos, cuja consecução assume o status de condição imprescindível para uma educação escolar que seja, de fato, indígena e gerida específica e autonomamente em todos os níveis.

Muito recentemente, algumas universidades brasileiras parecem ter compreendido sua importância para os povos indígenas, e mesmo para si próprias, e passaram a encampar esta demanda. Vê-se, assim, na atualidade, o surgimento de diversas iniciativas por todo o Brasil de projetos e cursos de formação superior de professores e professoras indígenas, principalmente no âmbito de instituições estaduais e federais. É neste contexto que surge também o curso de Licenciatura Intercultural para Formação Superior de Professores e Professoras indígenas da Universidade Federal de Goiás (doravante LI-UFG), universo mais amplo das reflexões aqui apresentadas.

A LI-UFG, que funciona regularmente desde seu início letivo, em 2007, inclui atualmente cerca de 200 acadêmicos e acadêmicas, ingressos/as através de exames vestibulares anuais, pertencentes aos povos Apinajé, Canela, Gavião, Guajajara, Guarani, Javaé, Kamaiurá, Karajá, Karajá Xambioá, Krahô, Krikati, Tapirapé, Tapuia, Xakriabá, Xavante e Xerente. Esses acadêmicos e acadêmicas vivem em diversas aldeias, em diferentes Terras Indígenas nos estados brasileiros de Goiás, Mato Grosso, Tocantins e Maranhão, e apresentam situações sociolinguísticas e culturais bastante diversificadas.

Como um dos principais objetivos do curso de LI-UFG, busca-se a formação de professores e professoras indígenas em nível superior, a 
ANDRÉ MARQUES DO NASCIMENTO - Desafios à elaboração curricular para a educação...

partir de um paradigma de educação emancipatório, descolonizante e concebido a partir das diferentes e particulares dimensões das vidas destes povos e do ideal de relações menos injustas entre esses e a sociedade não indígena, histórica e politicamente instituída como "a sociedade hegemônica".

Subjazem aos objetivos gerais do curso, as concepções de interculturalidade crítica e de transdisciplinaridade, diversidade e sustentabilidade, implementadas como princípios pedagógicos e eixos direcionadores dos diferentes processos e ações desenvolvidos nas atividades de formação docente. Neste sentido, como objetivo final e processo contínuo, espera-se que estes professores e professoras indígenas em formação superior sejam capazes de conduzir autonomamente a educação escolar de suas comunidades; reavivar e/ou implementar suas ontologias e epistemologias próprias na definição dos conhecimentos a serem abordados na escola; fazer com que estas epistemologias dialoguem criticamente com os conhecimentos oriundos das sociedades não indígenas e, consequentemente, que suas culturas, nelas incluídas suas práticas comunicativas originárias, tornem-se fortalecidas e menos propensas a situações de vulnerabilidades política, econômica e sociocultural.

Estes eixos e princípios se concretizam na orientação temática das matrizes curriculares do curso de LI-UFG, que se organizam em função de Temas Contextuais, e não de disciplinas, temas esses delineados por demandas específicas das comunidades indígenas através de suas lideranças, dentre elas professores e professoras indígenas, em áreas de conhecimentos que envolvem saberes indígenas e não indígenas sobre a cultura, a natureza e a linguagem e suas interações. Em outras palavras, as matrizes curriculares do curso são constituídas por Temas Contextuais que visam dar significado para os diferentes tipos de conhecimentos que se fazem relevantes para os projetos de vida e sustentabilidades dos povos indígenas brasileiros na contemporaneidade.

As matrizes curriculares da LI-UFG são compostas, ainda, por estudos que visam complementar os Temas Contextuais, chamados de Estudos Complementares, onde se situam, mais precisamente, estudos dedicados ao aprofundamento de práticas comunicativas nas línguas 
indígenas, na língua portuguesa - concebida como língua de relações interculturais ${ }^{2}$, na língua inglesa ${ }^{3}$, e conhecimentos de informática.

As atividades do Estágio Pedagógico da Licenciatura Intercultural, por sua vez, assumem caráter diferenciado daquele normalmente estabelecido nos cursos de Licenciatura, uma vez que os/as estudantes são, em sua maioria, professores e professoras das escolas indígenas. Assim, o Estágio não visa apenas à dimensão da preparação para o início da prática docente, constituindo-se também em um instrumento de formação em serviço, o que enriquece consideravelmente as experiências compartilhadas, pois essas se pautam nos desafios e enfrentamentos reais desses professores e professoras indígenas no cotidiano escolar.

É no contexto das atividades do Estágio que se desenvolvem com maior aprofundamento reflexões e práticas concernentes ao material didático específico e necessário para a educação intercultural, ao currículo das escolas indígenas, às pedagogias e metodologias interculturais e às diferentes e conflitantes relações entre conhecimento e poder em contexto intercultural. Estas atividades são retroalimentadas pelas pesquisas desenvolvidas pelos professores e professoras indígenas e consideram, no geral, a realidade sociolinguística das comunidades envolvidas, o contexto histórico e social dessas comunidades; além de seus projetos societários de vida e de futuro em situações de interações cada vez mais amplas e profundas com as sociedades não indígenas brasileiras.

No que se segue, busco apresentar experiências desenvolvidas por professores e professoras indígenas karajá xambioá e guarani mbyà nas atividades de Estágio Pedagógico da LI-UFG que, considerando o atual contexto de relações interculturais com a sociedade não indígena brasileira e seus conhecimentos, têm se emergido como importante locus de resistência contra-hegemônica a um paradigma de educação escolar colonizador e opressor.

Neste trabalho, enfoco exclusivamente as dimensões epistemológicas assumidas e implementadas por esses professores e professoras indígenas, e seu esforço pela orientação temática do

\footnotetext{
${ }^{2}$ Ver Nascimento (2012), para maior detalhamento.

${ }^{3}$ Ver Cotrim (2012), para maior detalhamento.
} 
ANDRÉ MARQUES DO NASCIMENTO - Desafios à elaboração curricular para a educação...

conhecimento local como ponto de partida para diálogos interculturais e transdisciplinares com os conhecimentos não indígenas e em detrimento da fragmentação disciplinar.

Argumento, neste sentido, que as experiências didáticopedagógicas e epistemológicas desenvolvidas no contexto do Estágio Pedagógico podem se tornar importantes bases para a elaboração curricular para as escolas indígenas desde uma perspectiva que faça com que a escola se transforme num espaço no qual os conhecimentos indígenas sejam, de fato, valorizados e desenvolvidos desde os interesses comunitários e dos projetos de vida e de futuro destes povos.

Destaco neste ponto, contudo, que as experiências de Estágio Pedagógico desenvolvidas no âmbito da LI-UFG não são as únicas que têm emergido como importantes bases para a fundamentação curricular das escolas indígenas. Outros importantes contextos de ensino e aprendizagem vinculados aos conhecimentos indígenas têm sido implementados e, de forma interconectada com as atividades de Estágio Pedagógico, têm se tornado, também, importantes fundamentos para a transformação da educação escolar indígena. Entre estes contextos, fazse necessário ressaltar as experiências a que temos chamado de Atividades Extraescolares, desenvolvidas paralelamente às atividades de Estágio Pedagógico, mas que com elas dialogam e se enriquecem mutuamente.

Muito embora os limites deste trabalho me impeçam de maior aprofundamento quanto às experiências advindas das Atividades Extraescolares (o que direcionou meu foco para as atividades de Estágio Pedagógico), considero relevante sua breve apresentação, pois, como poderá ser visto posteriormente, as reflexões elaboradas pelos professores e professoras indígenas desde este contexto embasam minha interpretação de que mesmo diante de constantes mudanças culturais pelas quais passam os povos Xambioá e Guarani da Terra Indígena Xambioá, bastante enfatizadas nos discursos de muitos e muitas indígenas da região, muitas são as manifestações das profundas permanências de aspectos culturais indígenas próprios de cada um destes povos 4 .

\footnotetext{
4 Agradeço imensamente a um(a) dos(as) pareceristas anônimos(as) deste texto pelas importantes e cuidadosas sugestões a mim enviadas para sua revisão, especialmente por me chamar a atenção para a
} 
De maneira geral, as Atividades Extraescolares visam ao desenvolvimento de contextos de ensino-aprendizagem pautados nas formas próprias de produção e transmissão de conhecimentos indígenas. É uma atividade eminentemente intracultural, ou seja, que se pauta exclusivamente em elementos considerados próprios das culturas indígenas, muito embora dialogue constantemente com a realidade gerada pelas relações interculturais, cujos temas de trabalho são pensados, liderados e desenvolvidos pelos professores e professoras indígenas em formação superior, contando sempre com o fundamental e imprescindível apoio de suas lideranças, de seus sábios e sábias e de suas comunidades. Os temas e conhecimentos 5 abordados visam à

importância das permanências culturais e da presença da ancestralidade indígena, mesmo diante de muitas transformações, percebidas como perdas por membros das populações Xambioá e Guarani da Terra Indígena Xambioá. De fato, é esta permanência e esta forte presença ancestral que torna viável a retomada e o revigoramento de conhecimentos e manifestações culturais, tanto no contexto da formação superior dos professores e professoras indígenas, como principalmente no contexto da educação escolar indígena. Considerando minha postura ética e minha decisão intelectual de respeitar e ouvir as vozes indígenas como interpretações teóricas válidas, reproduzi de maneira inquestionada na primeira versão deste texto suas percepções e afirmações sobre as constantes "perdas" culturais vivenciadas por seus povos nas últimas quatro ou cinco décadas; perdas estas tornadas mais salientes em seus discursos quando estes professores e professoras indígenas passaram a conviver na LI-UFG com professores e professores indígenas de outros povos que, por razões diversas, mantiveram mais preservadas manifestações culturais facilmente identificáveis como indígenas, como as práticas comunicativas em línguas indígenas, elementos de sua cultura material e ritualística, etc. Recentemente, contudo, os professores e professoras indígenas Xambioá e Guarani, em mais um movimento de liderança entre os membros de suas comunidades, passaram a questionar de forma mais crítica a ideia de perda cultural e mesmo a de revitalização cultural, já que, conforme comunicação pessoal de um de seus professores, "não se revitaliza ou resgata o que não está morto". A decisão de manter neste texto certa ênfase em aspectos antes percebidos como perda pelos professores e professoras indígenas, e ainda hoje pelos demais membros de suas comunidades, tem como intuito maior destacar as decisões e ações implementadas pelos professores e professoras indígenas no desafio de transformar a educação escolar coerentemente com os interesses de suas comunidades, dentre os quais figuram-se de forma incisiva o uso regular de práticas comunicativas em línguas indígenas em sociedade, a prática de manifestações culturais como danças, cantos, pinturas e adornos corporais etc. com maior frequência, além da valorização e da implementação de epistemologias indígenas, que jamais fizeram parte de sua educação escolar. Mesmo diante desta explicação, considero importante esclarecer que qualquer falha interpretativa presente neste texto é de minha inteira responsabilidade.

5 De maneira geral, nas comunidades da Terra Indígena Xambioá, as Atividades Extraescolares implementadas pelos professores e professoras indígenas têm sido desenvolvidas a partir de três etapas complementares importantes: Pesquisas junto aos/às conhecedores/as das culturas indígenas sobre os temas escolhidos para serem desenvolvidos, considerando sua importância no contexto sociocultural específico de suas comunidades. Até o momento, os acadêmicos e acadêmicas Karajá Xambioá e Guarani desenvolvem atividades partindo dos seguintes temas: "A revitalização do artesanato tradicional do povo Karajá Xambioá" (trabalho concluído em 2011, ver Wajurema Karajá et al. (2011)); "Hábitos alimentares tradicionais do povo Karajá Xambioá" (trabalho concluído em 2012, ver Curarrá Karajá e Lima Karajá, (2012)); "Hábitos alimentares tradicionais do povo Guarani Mbyà" (Guarany Silva (2013) em andamento) e "O artesanato feminino Karajá Xambioá: Ritxoko" (Txebuare Karajá (2013) em andamento); Documentação através da sistematização dos conhecimentos oriundos das atividades de pesquisa, com o objetivo de torná-los disponíveis para toda a comunidade e principalmente para possíveis usos na educação escolar, como recursos didáticos; Realização de oficinas com a participação de jovens e

Espaço Ameríndio, Porto Alegre, v. 7, n. 1, p. 95-145, jan./jun. 2013. 
ANDRÉ MARQUES DO NASCIMENTO - Desafios à elaboração curricular para a educação...

sustentabilidade dessas comunidades, seja na dimensão cultural, sociolinguística ou mesmo econômica. Sustentabilidade compreendida neste contexto conforme Lima Guarani (2012, p. 5, destaque no original):

Por sustentabilidade, entendo que nada mais é do que a forma, a vontade e o interesse que um determinado povo tem de não deixar que algo que é de seu interesse desapareça. E a criatividade do povo na hora de criar planos, projetos, que venham satisfazê-lo de uma forma que ele possa permanecer vivo e forte é muito importante. E o fator principal, responsável pela existência da sustentabilidade chama-se ação, vontade própria em primeiro lugar (LIMA GUARANI, 2012, p. 5, grifos no original).

Em muitos contextos, as Atividades Extraescolares têm construído pontes entre os conhecimentos ancestrais das comunidades e as novas gerações, através de propostas que visam à interação entre os sábios e sábias indígenas e os/as jovens, reativando, assim, formas de produção e transmissão próprias do conhecimento e fomentando o uso das línguas indígenas vinculadas aos seus contextos de produção. Também a partir destes contextos, importantes insights sobre o que sejam os "processos próprios de aprendizagem", cuja compreensão desafia tanto os professores e professoras indígenas como os professores e professoras não indígenas formadores/as, têm emergido de forma cada vez mais esclarecedora, muito embora ainda iniciais ${ }^{6}$.

A Atividade Extraescolar tem como um de seus objetivos principais a elaboração e a implementação, pelos acadêmicos e acadêmicas indígenas, de projetos comunitários que visem à sustentabilidade linguística, cultural, social e/ou econômica de suas aldeias em parceria com os/as especialistas das culturas indígenas, na

crianças, contextos nos quais os anciãos e as anciãs transmitem conhecimentos sobre os temas escolhidos. A proposta central desta etapa da Atividade Extraescolar é colocar os/as jovens em contado com a sabedoria tradicional e promover um espaço de prática e vivência dessa sabedoria. Para isso, os acadêmicos promovem e articulam encontros entre os/as jovens e os/as especialistas indígenas, para que eles e elas expliquem para os/as mais jovens aspectos dos temas abordados. As oficinas têm um caráter prático, ou seja, os/as jovens começam a aprender a fazer e a praticar o que é ensinado pelos/as mais velhos.

6 A reflexão mais aprofundada sobre as Atividades Extraescolares e suas contribuições para a fundamentação da educação escolar indígena está sendo elaborada e melhor desenvolvida em outro trabalho.

Espaço Ameríndio, Porto Alegre, v. 7, n. 1, p. 95-145, jan./jun. 2013. 
ANDRÉ MARQUES DO NASCIMENTO - Desafios à elaboração curricular para a educação...

maior parte dos casos, os anciãos e anciãs, a partir do levantamento dos interesses comunitários. Assim, para a realização desta atividade, tornase fundamental, antes de tudo, compreender que a sustentabilidade não é uma propriedade individual, mas uma propriedade de toda uma rede, pois sempre envolve a comunidade na sua totalidade (CAPRA, 2006).

Trata-se, pois, de uma atividade eminentemente societária, comunitária, cujo escopo visa incidir sobre práticas culturais consideradas relevantes pelas comunidades dos professores e professoras indígenas que possam ser abordadas em contextos fora da escola e que, principalmente, consiga o engajamento e o interesse de crianças e jovens para tais práticas. O foco no trabalho com jovens e crianças indígenas visa ainda promover e preencher espaços nos quais, dadas as transformações socioculturais vivenciadas pela maior parte das comunidades dos acadêmicos e acadêmicas indígenas da UFG, esses grupos estariam sujeitos a várias formas de vulnerabilidade social, como o alcoolismo, o uso de drogas, a prostituição, doenças etc.

Desta forma, um importante desdobramento desta atividade, e mesmo sua principal condição de realização, é o reavivamento ou o fortalecimento das relações entre esses/as jovens e os anciãos e anciãs e de contextos de ensino-aprendizagem não escolares, em que 0 conhecimento próprio de cada cultura, sobre diferentes aspectos e de maneira interconectada, possam ser transmitidos dos/as mais velhos/as para os/as mais jovens e, assim, se reforcem e/ou se tornem mais valorizados e difundidos socialmente. Neste contexto, os professores e professoras indígenas tornam-se os articuladores/as deste movimento e, muitas vezes, aprendem juntamente com os/as jovens de suas comunidades aspectos importantes do conhecimento de seu povo.

No caso das comunidades da Terra Indígena Xambioá, o desenvolvimento de uma atividade extraescolar que propicie o reavivamento e o fortalecimento de práticas socioculturais próprias toma uma importância muito grande, pois a configuração dessas comunidades apresenta rupturas na transmissão dos conhecimentos indígenas dos/as mais velhos/as para os/as mais jovens que, de modo geral, já não se interessavam e não queriam mais aprender com seus anciãos e anciãs, especialmente se se tratava de conhecimentos locais. De acordo com a anciã Violeta Karajá, os jovens já não queriam mais 
ANDRÉ MARQUES DO NASCIMENTO - Desafios à elaboração curricular para a educação...

conhecer aspectos de sua própria cultura e alguns/as anciãos e anciãs já não tinham mais vontade de ensinar?

Outro aspecto importante referente à realização da Atividade Extraescolar pelos professores e professoras indígenas karajá xambioá e guarani é a oportunidade de criação de contextos de usos e práticas comunicativas em línguas indígenas, onde estas se tornam meios de transmissão de conhecimentos, abrindo espaço para que os/as jovens aprendam, juntamente com as práticas tradicionais, aspectos comunicativos especializados em suas línguas para diferentes situações socioculturais.

Na seção seguinte, e em coerência com o fundamento básico da especificidade local da elaboração curricular para as escolas indígenas, são apresentadas informações que muito sinteticamente apresentam aspectos da realidade dos povos Karajá Xambioá e Guarani Mbyà da Terra Indígena Xambioá, a fim de situar suas demandas específicas quanto à função das escolas de suas comunidades a serem concretizadas no currículo escolar.

\section{Aspectos socioculturais dos povos Karajá Xambioá e Guarani da Terra Indígena Karajá Xambioá}

Os Karajá Xambioá, ou Karajá do Norte, constituem um povo que, como seus parentes Karajá e Javaé, são classificados pela linguística hegemônica ocidental como pertencentes ao tronco linguístico MacroJê, à família linguística Karajá e como falantes da língua karajá. Em suas próprias designações, entretanto, constituem o Iny mahãdu (povo Iny) e são falantes do iny rybè (nossa fala, fala do povo Iny). Pelo pouco que conheço de suas formas próprias de organização sociocultural, não se trata, contudo, de designações facilmente intercambiáveis ou mesmo traduzíveis.

Por tradicionalmente habitarem às margens do baixo curso do Berohokỹ (Rio Grande ou Rio Araguaia), de vital importância para sua existência física e cosmológica, são conhecidos entre os povos Iny (Karajá e Javaé) como Iraru Mahãdu (povo de baixo) ou como Ixỹ biawa,

\footnotetext{
${ }^{7}$ Em comunicação pessoal, em maio de 2012, na Aldeia Wari-Lỹtỹ.
} 
ou ainda Ixỹbiòwa (povo amigo, povo companheiro), de onde proviria a denominação Xambioá (RODRIGUES, 2008).

A história não indígena remonta seu "contato" com as sociedades não indígenas ao século XVII, em relatos de assaltos de paulistas às suas aldeias (TORAL, 1992), contatos estes que foram se intensificando paulatinamente ao longo dos séculos, para prejuízo deste povo. Segundo Toral, durante o século XIX, as aldeias do povo Karajá Xambioá chegaram a ocupar $240 \mathrm{~km}$ de extensão do rio e "eram referidos por todos os que os visitavam como o mais próspero dos grupos Karajá, com as maiores e mais populosas aldeias" (TORAL, 1992, p. 26). Tal prosperidade, no entanto, não resistiu por muito tempo e, conforme atesta o autor,

a partir do final do séc. XIX em diante, os efeitos dos choques com guarnições militares dos "presídios" construídos na região para vigiá-los e garantir a navegação, da repressão promovida por missionários capuchinhos aliados à violenta aparição de epidemias causaram o desmoronamento de sua população e uma mudança na composição dos grupos. Cerca de aproximadamente 2.000 pessoas em 1842 declinam para 1.350 em 1887, 60 em 1940 e 40 pessoas em 1959, o número mais baixo que jamais atingiram (TORAL, 1992, p. 28).

A partir das décadas de 1940 e 1950, sob comando do Serviço de Proteção aos Índios (SPI), este povo começou a se estabelecer nas proximidades de onde hoje se situa, com o objetivo de maior controle sobre sua população, sob a alegação de facilitar a assistência. A partir da década de 1950, principalmente, toda a população já estava reunida na área atual.

Hoje, o povo Karajá Xambioá vive na Terra Indígena Xambioá, localizada ao norte do estado do Tocantins, próxima ao município de Santa Fé do Araguaia. Segundo dados do Instituto Socioambiental (ISA, 2012), a área oficial da Terra Indígena Xambioá é de 3.326 hectares, muito embora pelos cálculos do Instituto seja, de fato, de 3.290 hectares. De toda forma, trata-se de uma área infinitamente menor do que a que costumavam habitar ancestralmente.

De modo geral, é uma área ambiental relativamente preservada, 
ANDRÉ MARQUES DO NASCIMENTO - Desafios à elaboração curricular para a educação...

onde ainda se concentram grandes extensões de matas virgens, da fauna e da flora nativas, diferentemente das regiões circunvizinhas, ocupadas por fazendeiros, onde a devastação ambiental já é bem evidente. Recentemente, contudo, a população da área xambioá tem sentido de maneira mais próxima os impactos ambientais causados principalmente pelas queimadas e pela poluição do rio Araguaia, sua principal fonte de recursos alimentícios, pois trata-se de um povo pescador por excelência.

A Terra Indígena Xambioá é composta hoje por quatro aldeias, Aldeia Xambioá, Aldeia Wary-Lỹtỹ, Aldeia Kurehê e a Aldeia HawaTymara, constituídas predominantemente por famílias Karajá Xambioá, mas também por um grande número de famílias Guarani Mbyà. Muitas são ainda as famílias constituídas através de casamentos interétnicos entre indígenas e não indígenas.

Os dados demográficos referentes à população da Terra Indígena Xambioá, como ocorre com os povos indígenas brasileiros no geral, são variáveis e imprecisos. Conforme o IBGE (2012), na área rural do município de Santa Fé do Araguaia, o que certamente se refere às aldeias da região, haveria 295 indígenas. Segundo dados da FUNASA (2011) apresentados pelo Instituto Socioambiental (ISA, 2012), o número seria de 297, somando-se a população Karajá Xambioá e Guarani. Para o cacique da Aldeia Xambioá, no entanto, este número seria bem maior, aproximando-se de 400 pessoas nas quatro aldeias ${ }^{8}$.

A presença Guarani na Terra Indígena Xambioá iniciou-se há, ao menos, mais de trinta anos, com o estabelecimento na região de famílias oriundas do sul do país, principalmente do Mato Grosso do Sul. Pode-se constatar na atualidade a convivência harmoniosa entre este e o povo Karajá Xambioá, concretizada no respeito mútuo às práticas e formas de vida próprias de cada povo e, em muitos casos, nas famílias constituídas através da união de membros destes diferentes povos.

Conforme Ladeira (2003), os Guarani Mbyà, que se autorreconhecem coletivamente como Nandeva ekuèry ('todos os que somos nós'), constituem um dos povos indígenas de maior presença territorial no Brasil; e a despeito da dispersão geográfica e das diferentes relações com as sociedades não indígenas e com outras

\footnotetext{
${ }^{8}$ Em comunicação pessoal, em maio de 2011.
} 
ANDRÉ MARQUES DO NASCIMENTO - Desafios à elaboração curricular para a educação...

sociedades indígenas, mantêm uma unidade religiosa e linguística bem determinada, que permite o reconhecimento de seus iguais, mesmo vivendo em aldeias separadas. Aliás, a dispersão geográfica e o constante êxodo é uma das principais características deste povo, o que faz com que estejam presentes em diferentes regiões do país. Segundo Ladeira,

os Mbya estão presentes em várias aldeias na região oriental do Paraguai, no nordeste da Argentina (província de Misiones) e no do Uruguai (nas proximidades de Montevidéu). No Brasil encontram-se em aldeias situadas no interior e no litoral dos estados do sul - Paraná, Santa Catarina, Rio Grande do Sul - e em São Paulo, Rio de Janeiro e Espírito Santo em várias aldeias junto à Mata Atlântica. Também na região norte do país encontram-se famílias Mbya originárias de um mesmo grande grupo e que vieram ao Brasil após a Guerra do Paraguai, separam-se em grupos familiares e, atualmente, vivem no Pará (município de Jacundá), em Tocantins numa das áreas Karajá de Xambioá, além de poucas famílias dispersas na região centro-oeste. No litoral brasileiro suas comunidades são compostas por grupos familiares que, historicamente, procuram formar suas aldeias nas regiões montanhosas da Mata Atlântica - Serra do Mar, da Bocaina, do Tabuleiro, etc. (LADEIRA, 2003, p. 2).

Esta dispersão geográfica é explicada ainda pela cosmologia guarani, como apresentada abaixo, no relato de uma de suas versões, por Guarany Silva:

Há muitos anos atrás, os Guarani viviam todos juntos numa mesma aldeia, onde existia um grande líder, o Ñanderu, que recebia mensagens de Deus e passava para o povo, dizendo como o povo deveria proceder neste mundo para alcançar um lugar de paz e descanso, "a terra sem males". Mas o povo começou a desobedecer ao Ñanderu que ficou muito irritado e disse para o povo que por causa da desobediência deles, ele iria morrer, mas o povo não iria mais conseguir viver unido. $O$ povo iria se espalhar, ia ficar sem rumo e, assim, aconteceu. Isso explica a existência de índios Guarani por todo canto da terra (GUARANY SILVA, 2011, p. 15).

A tradição etnolinguística hegemônica classifica as práticas 
ANDRÉ MARQUES DO NASCIMENTO - Desafios à elaboração curricular para a educação...

comunicativas do povo Mbyà, assim como as de seus parentes Kaiowa e Ñandeva, como dialetos do idioma Guarani, pertencente à família linguística Tupi-Guarani e ao tronco Tupi. Segundo um de seus professores indígenas residentes na Terra Indígena Xambioá, contudo, as práticas comunicativas próprias são nomeadas de Nandè Ayu ('nossa palavra').

A presença de não indígenas, por sua vez, ao que indicam os relatos das pessoas mais velhas das aldeias, é mais antiga, datando, pelo menos, de finais da década de 1960 e início de 1970. A presença de não indígenas, assim como a do povo Guarani, foi, em determinado momento, crucial para o restabelecimento quantitativo do povo Karajá Xambioá, quando de sua maior redução populacional, conforme analisa Toral,

foi a incorporação dos regionais [não-indígenas] e dos Guarani que permitiu a recuperação populacional, impedindo a extinção física na década de 1960, quando os Karajá do Norte foram reduzidos a apenas 40 pessoas, devido à irrupção violenta de diversos tipos de moléstias, alcoolismo e lutas internas (TORAL, 2001, p. 4).

Contudo, se por um lado a presença não indígena contribuiu com a manutenção física do povo Karajá Xambioá, através de casamentos interétnicos, por outro lado contribuiu também com mudanças significativas em seus costumes e tradições étnicos próprios. Como analisa Toral,

do início de 1970 até 1982 foram contraídas 14 uniões com pessoas da região. Nesta última data viviam na aldeia nove regionais, cinco homens e quatro mulheres. Essas uniões com regionais explicam-se parcialmente em função da grande distância em relação às aldeias Karajá mais próximas (mais de 100 km rio "acima", i.e. ao sul) e também devido às relações sempre tensas entre as famílias reunidas na aldeia "do Posto". Se por um lado essas uniões permitiram a recuperação populacional do grupo, por outro, causaram considerável abalo na manutenção de certos aspectos da cultura Karajá do Norte. A vida ritual foi muito simplificada, restringindo-se, em 1982, à montagem de algumas fases da cerimônia de iniciação dos rapazes. A língua é falada, grosso modo, apenas pelos maiores de 
ANDRÉ MARQUES DO NASCIMENTO - Desafios à elaboração curricular para a educação...

15 anos. Os demais têm uma relação "passiva" com a língua: entendem, mas não falam. Mantiveram-se, no entanto, como uma comunidade discreta em meio aos núcleos regionais vizinhos, reconhecendo-se e fazendo questão de serem reconhecidos como "índios" e "Karajá" (TORAL, 1992, p. 31).

Da década de 1980 (quando da pesquisa de Toral) aos dias atuais, a tendência das mudanças socioculturais do povo Karajá Xambioá seguiu a mesma trajetória, tornando-se ainda mais acentuada, no entanto. Hoje, segundo relato dos anciãos e anciãs xambioá e de seus professores e professoras indígenas, a população mantém pouco de seus costumes e tradições próprios, se comparada a pelo menos quatro ou cinco décadas atrás. Segundo esses depoimentos, a presença não indígena - atualmente muitíssimo maior, seja através de casamentos, seja através de suas instituições, como a escola ou a igreja - parece ter sido o principal fator para transformações socioculturais ocorridas, especialmente, a partir da década de 1960.

No que diz respeito às práticas comunicativas em Iny rybè, por exemplo, se até a década de 1980 as pessoas maiores de 15 anos ainda faziam uso delas, hoje a situação é bem diferente. Minha atuação como coordenador do comitê orientador dos acadêmicos e acadêmicas karajá xambioá e guarani, através das reflexões originadas no diálogo com esses professores e professoras na universidade e em suas comunidades, permitiu-me constatar que, nas aldeias da Terra Indígena Xambioá, as práticas comunicativas em língua portuguesa são as mais difundidas e têm se firmado como as primeiras adquiridas por seus membros. O ensino de práticas comunicativas em Iny rybè, como "segunda língua", tem se restringido principalmente à escola, uma vez que há um número muito pequeno de falantes de Iny rybè, em sua maioria anciãos e anciãs que, além de tudo, residem em aldeias diferentes, o que dificulta ainda mais as interações sociais cotidianas.

A situação sociolinguística das comunidades guarani residentes na Terra Indígena Karajá Xambioá é um pouco diferente, uma vez que a língua Guarani é usada numa base regular bem mais intensa do que a língua Karajá, muito embora já seja perceptível uma mudança no padrão aquisicional em direção à aquisição inicial de práticas comunicativas 
ANDRÉ MARQUES DO NASCIMENTO - Desafios à elaboração curricular para a educação...

originalmente não indígenas ${ }^{9}$.

Neste contexto, a educação escolar conforme desenvolvida nas aldeias tem sido uma das causas e a principal fomentadora do desuso de práticas comunicativas em Iny Rybè, segundo avaliam anciãos e anciãs das aldeias ${ }^{10}$.

Atualmente, na Terra Indígena Xambioá, há três escolas de Ensino Fundamental e um Centro de Ensino Médio Indígena, regidas pelo sistema estadual de ensino do estado do Tocantins. Muito embora funcionem sob a qualificação de escolas indígenas, até o momento, com poucas e pontuais exceções, operam excluindo os conhecimentos indígenas em todas as suas dimensões, inclusive comunicativas, fragmentando os conhecimentos e tratando o Iny rybè como uma disciplina, como analisam os próprios professores indígenas Kumare Karajá e Lima Guarani. Em suas palavras,

Hoje, o ensino na escola Karajá está focalizado nos conhecimentos ocidentais, obedecendo aos critérios adotados pelos colonizadores. Pouca atenção é dada para 0 aprendizado de suas realidades (KUMARE KARAJÁ, 2011, p. 4).

Em se tratando de educação bilíngue, não tenho nem palavras para expressar como experiência própria, porque não sou falante da língua Karajá Xambioá. Todavia, o que posso comentar sobre o assunto é que na escola em que trabalho existem, de fato, professores bilíngues em português e em iny rybè. $E$ pelo pouco que entendo do tema, e pelo que observo, vejo que na escola ainda não temos o verdadeiro sistema de educação bilíngue, porque trata-se, então, de um projeto amplo, que envolve os alunos, em sala de aula e fora dela, como a comunidade inteira, e sem tempo determinado. $O$ que vejo acontecer onde trabalho é o ensino de duas línguas, e não uma educação bilíngue, porque a língua iny, principalmente, só é aplicada em sala de aula e com dias e minutos marcados. E nesse caso, vejo que a língua iny é vista como uma disciplina à parte. É como se tivesse a mesma importância que uma outra disciplina qualquer, o inglês, por exemplo. Então, a educação bilíngue não é

\footnotetext{
${ }^{9}$ Ver Nascimento (2012) para maior aprofundamento da situação sociolinguística dos povos da região.

${ }^{10}$ Esta constatação me foi apresentada, em momentos distintos, pelo ancião Bòròri Karajá e pela anciã Violeta Karajá, duas importantes lideranças do povo Xambioá, respectivamente em setembro de 2010 e em maio de 2011.
} 
ANDRÉ MARQUES DO NASCIMENTO - Desafios à elaboração curricular para a educação...

o que vejo na escola em que trabalho, pois teremos que nos reunir, todo o "corpo da escola" e comunidade, para conversar sobre o fato, esclarecendo a importância que tem a língua iny, e que nunca é tarde para a gente adotar, de fato, a educação bilíngue intercultural em nossa escola (LIMA GUARANI, 2012, p. 6-7).

É também a partir da década de 1960 que algumas práticas tradicionais referentes à cultura material dos Karajá Xambioá entram em declínio (WAJUREMA KARAJÁ et al., 2011). Desde então, a confecção de peças artesanais passou a ser cada vez menos praticada entre sua população a ponto de as gerações mais novas não conhecerem-nas. Da mesma forma, até bem recentemente, a ornamentação corporal, através de enfeites e da pintura corporal, não era observada entre os Karajá Xambioá. Segundo relatos dos professores e professoras indígenas, durante muito tempo, os/as jovens se sentiam envergonhados/as de serem vistos, principalmente nos municípios próximos, pintados/as ou caracterizados/as como índios/as. O sentimento de vergonha étnica imputada aos jovens indígenas karajá xambioá certamente é a principal e mais cruel consequência humana nestas transformações.

As mudanças socioculturais, como não são isoladas ou pontuais, mas interconectadas e de ampla magnitude, abrangeram muitas outras dimensões da vida do povo Karajá Xambioá, sendo umas mais visíveis ou perceptíveis do que outras, como se observa, por exemplo, nos hábitos alimentares atuais (CURARRÁ KARAJÁ e LIMA KARAJÁ, 2012).

Se a pesca e a captura de peixes e de outros animais aquáticos, como a tartaruga e o tracajá, continuam sendo importante base da alimentação e da cosmologia deste povo, elas já não são mais praticadas da mesma forma. Poucas são as pessoas que ainda pescam com arco e flecha ou usam formas indígenas de captura. Práticas de pesca predatória têm cada vez mais sido usadas na região por pescadores não indígenas, principalmente, mas também por indígenas menos conscientes e/ou menos favorecidos, visando à comercialização dos peixes, como constatam seus professores e professoras indígenas:

Hoje, os peixes consumíveis pelos Ixỹbiòwa já não são encontrados com abundância. A escassez de peixes como o jaraqui, o tucunaré, o pacu, o filho d'água, o 
ANDRÉ MARQUES DO NASCIMENTO - Desafios à elaboração curricular para a educação...

curimatá e outros, se deu por causa pesca predatória com uso de materiais industrializados, como a tarrafa e as redes, através do método de pesca do arrastão, técnica hoje inserida dentro das comunidades indígenas locais, que por sua vez estão esquecendo a pesca tradicional artesanal com arco e flecha e outros meios culturais (CURARRÁ KARAJÁ et al., 2010, p. 16-17).

As consequências destas práticas predatórias têm se tornado cada vez mais latentes com a extinção de certas espécies de peixes e a drástica redução de outras. A pesca tem, assim, se tornado mais difícil, e a necessidade de se distanciar das aldeias para encontrar os peixes e as tartarugas é cada vez maior.

O impacto das mudanças atingiu ainda outras formas de produção de alimentos. A prática de cultivo de roças para plantação de víveres que fazem parte dos hábitos alimentares tradicionais do povo Karajá Xambioá também se tornou obsoleta, quase desaparecendo completamente ao longo das décadas, como analisa a professora Eva Lima Karajá, em uma de suas pesquisas:

Na década de 1960, na comunidade Karajá de Xambioá, ainda havia muita fartura de alimento das roças. As famílias tinham o costume de fazer grandes roças, os homens trabalhavam em mutirão em que um grupo de pessoas se reunia para fazer juntas uma roça bem grande. O resto do povo fazia seus trabalhos individualmente em pequenas roças, mas todos trabalhavam. Nas roças, eles plantavam todo tipo de alimento cultivado na terra, que atendiam suas necessidades. Os alimentos cultivados eram mandioca, inhame, batata, banana, abóbora, melancia, macaxeira etc. Ao longo dos anos, isso foi mudando. O trabalho em mutirão acabou. [...] Com o tempo, os hábitos foram mudando, as terras foram sendo desmatadas em grande extensão. Devido as roças serem feitas de qualquer jeito, sem pensar na natureza. Pela falta de organização, a cada ano uma roça foi sendo feita em lugares diferentes. Hoje, grande parte da reserva está desmatada, com isso os animais foram desaparecendo, tanto os grandes como os pequenos. Os caçadores já reclamam de uma dificuldade para matar uma caça para o seu alimento no dia a dia. Devido a isso, mudou toda a alimentação dessa comunidade, pois já não se plantam os alimentos tradicionais. Todo o alimento tem vindo da cidade, do supermercado, e por vários 
ANDRÉ MARQUES DO NASCIMENTO - Desafios à elaboração curricular para a educação...

motivos esse alimento [tradicional] já não é mais consumido. Às vezes não é encontrado no comércio, às vezes o dinheiro é pouco e não dá para levar tudo que necessita. Enfim, muitas comidas do passado não são consumidas mais hoje (CURARRÁ KARAJÁ e LIMA KARAJÁ, 2012, p. 12-13).

Dentre os principais impactos advindos das mudanças nos hábitos alimentares do povo Karajá Xambioá, o mais preocupante é a ocorrência de doenças relacionadas ao consumo de alimentos industrializados, como o sal, o açúcar e o óleo, o que tem originado problemas como a hipertensão e a diabetes, entre outros (CURARRÁ KARAJÁ e LIMA KARAJÁ, 2012).

No que concerne às práticas religiosas ou ritualísticas, se na década de 1980, conforme Toral (1992), ainda eram realizadas partes da cerimônia de iniciação da vida adulta dos rapazes, o Hetohokỹ, na atualidade elas foram transformadas. Apenas a representação dos karalahuni ou Kralahu, guerreiros que morreram em combate, ainda é praticada em situações festivas (CURARRÁ KARAJÁ e LIMA KARAJÁ, 2012, p. 79). Por outro lado, a presença de igrejas e de missionários/as evangélicos/as é muito forte, tendo, ao longo dos anos, conseguido converter muitos indígenas às suas crenças, o que de muitas formas reforça as mudanças socioculturais entre este povo.

Mesmo diante deste panorama de constantes e abruptas mudanças socioculturais e das inúmeras pressões externas que as impulsionam, meu convívio com este povo me permite constatar que o que melhor lhes caracteriza e identifica na atualidade é um profundo e comovente sentimento de pertencimento étnico e de identidade indígena. Trata-se de uma dimensão de suas vidas que as diferentes formas de violência parecem não ter conseguido suprimir ao longo dos tempos. Trata-se de exemplos constantes de resistência, de reexistências do povo Karajá Xambioá. A mesma resistência secular observada entre o povo Guarani que vive nesta região.

É precisamente este sentimento que tem motivado, na atualidade, ações em prol do fortalecimento e da valorização de aspectos considerados nucleares de suas culturas, como do uso do Iny Rybè e do Nandè ayu, das práticas artísticas tradicionais, dos hábitos alimentares próprios xambioá e guarani, da preservação do meio ambiente local, do 
ANDRÉ MARQUES DO NASCIMENTO - Desafios à elaboração curricular para a educação...

fortalecimento da relação entre jovens e anciãos e anciãs, enfim, de diversas dimensões de sua sustentabilidade enquanto povos indígenas.

Neste contexto, torna-se imprescindível a compreensão mais aprofundada de que o que muitos indígenas xambioá e guarani interpretam como perda de suas culturas pode ser melhor compreendido, como já tem sido por seus professores e professoras, como um estado de desuso, ou de menor uso, pois em todas as situações em que os conhecimentos indígenas, em suas mais variadas formas, foram necessários nas atividades implementadas no âmbito da LI-UFG e mesmo fora dele, eles foram pronta e facilmente encontrados nos ensinamentos de adultos/as, anciãos e anciãs, como atestam algumas reflexões produzidas durante a realização das Atividades Extraescolares, por exemplo:

Esse trabalho que vem surgindo e dando alegria ao povo, é graça a uma visão de educação do povo voltada para o povo. É um trabalho de resgate principalmente da auto-estima do povo guarani de Xambioá, que nasceu junto com o curso de Licenciatura Intercultural Indígena da UFG em Goiânia. [...] O que é mais importante ressaltar foi como esse trabalho motivou o povo. Foi muito bom ver a alegria das pessoas. Foi um momento em que os mais velhos voltaram a sentir um pouco de como era a vida em comunidade. $\mathrm{O}$ trabalho despertou o desejo de viver coletivo e a união. Eu, particularmente, fiquei emocionado, senti que estava vivendo algo nunca vivido com o meu povo, vendo os mais velhos falando na língua, brincando, sorrindo e os jovens ali juntos. Isso me alegrou muito. Minha tia que estava nos visitando, que mora na aldeia dos Guarani no Jacundá, Pará, ficou impressionada e disse que gostaria que isso acontecesse sempre, pois era assim que o povo vivia. Essa declaração foi muito forte para mim, que organizamos a atividade com muita dificuldade, mas que mostra que podemos ser fortes culturalmente, mesmo morando na terra dos outros parentes (GUARANY SILVA, 2013).

Os alunos estavam olhando os anciãos fazerem e cada aluno tentava fazer a hawàriòre. Isso é muito importante para o povo Karajá Xambioá, porque estão buscando a sua cultura (KRUMARE KARAJÁ, 2011a, p. $65)$. 
No momento da construção, as histórias sobre os costumes tradicionais foram realmente uma lição de vida para todos nós. $E$, assim, ficou claro que tanto esses conhecimentos quanto outros, se expandem, produzem mais efeitos em momentos assim, em uma reunião, em espaço livre. Os meninos se sentem mais à vontade, não se restringem. Conversam, perguntam os velhos. Assim é que, a partir dessa nova forma de aprendizagem, e pelo rendimento que teve, eu passei a fazer, em alguns momentos, aulas extraclasse, porque assim a gente passa a lidar diretamente com a realidade. $\mathrm{E}$ o que passei a entender nos últimos tempos é que temos que sair da abstração, da subjetividade (LIMA GUARANI, 2011, p. 69).

No momento que ocorre a atividade extraescolar, os anciãos transmitem conhecimentos em forma da oralidade, contando histórias, sobre como o artesanato era usado no passado, em nossa comunidade. Com sua cosmovisão, os velhos vêm ajudando na revitalização da cultura Xambioá. Nós acadêmicos da UFG aprendemos bastante juntamente com os alunos das nossas aldeias. Com esse trabalho podemos refletir sobre a nova política de educação para o Karajá, valorizando o conhecimento de mundo de cada sociedade e fazendo pesquisa sobre a origem de cada peça que foi trabalhada no projeto extraescolar (KUMARE KARAJÁ, 2011b, p. 71).

A parte da cerâmica quem comandou foi a senhora Violeta. Ela pegou o barro e começou a fazer os artesanatos e com ela estavam todos os alunos observando aquela arte. $\mathrm{E}$ ali muitos começaram também a fazerem os artesanatos. Depois o Sr. Lawari começou a fazer o behyra com as palhas de bacaba e todos nós estávamos atentos, observando todos os detalhes. Alguns alunos pegaram a palha e foram aprendendo a arte. De certo que os trabalhos do dia foram muito divertidos e produtivos. Satisfeitos, todos nós acadêmicos, alunos e anciãos findamos as atividades do dia (LIMA GUARANI, 2011, p. 43).

Fizemos as atividades em dois momentos: um no período matutino e o outro no vespertino. O matutino foi na casa do prof. Mauro, como foi citado anteriormente, e o outro foi debaixo de um pé de mangueira, na beira do rio Araguaia. Antes de nós iniciarmos as nossas atividades, fizemos um acordo entre nós para trabalhar o artesanato de madeira. Em seguida surgiu um artesanato interessante, que 
antigamente os Karajá Xambioá usavam bastante. Chama-se oluò, não tem nome em português (WAJUREMA KARAJÁ, 2011, p. 67).

E ali sentado, o ancião Lawari pegou 6 talos de buriti e juntou-os, sendo metade deles com lados opostos da outra metade, depois pegou a palha e começou a enrolar nesses talos, fazendo com que estes se tornassem em uma unidade mais resistente. E como o momento era de aprendizagem, as crianças começaram a fazer do mesmo jeito. Rapidamente já se tinham várias peças prontas (LIMA GUARANI, 2011, p. 93).

Nós, acadêmicos indígenas Karajá Xambioá e Guarani da turma de 2007, tivemos muito o que aprender com o trabalho da Atividade Extraescolar desenvolvido em nossas aldeias. Descobrimos que não basta a teoria sem levar em consideração os atos práticos da cultura. Com essa atividade, aprendemos que é necessário conciliar as teorias com as práticas, pontos considerados imprescindíveis para a elaboração de um projeto de revitalização da cultura, como é o nosso caso. Tomamos conhecimento de que os saberes universais adquiridos por nós em escolas do não-índio não foram o suficiente para dar a sabedoria necessária para a nossa realidade. E assim os anciãos foram realmente os verdadeiros protagonistas destas atividades (WAJUREMA KARAJÁ et al. 2011, p. 168169).

Os alunos e jovens que estavam presentes na hora da preparação do bòròrò ficavam só observando e anotando o que a anciã ensinava e explicava. Esta atividade pode contribuir muito, porque eu percebo que na atualidade esse espaço já se encontra vazio, porque antes, a tradição e a sabedoria indígena era passada de pai para filho na prática diária, sem a intervenção da escrita e teoria. Então, este trabalho foi importante para fazer valorizar os nossos alimentos tradicionais, porque o povo passou a ver a comida que já estava fugindo da nossa realidade. Então, afirmo que foi muito importante essa experiência com os alunos, de mostrar para eles a realidade de nosso povo. Com certeza os jovens e as crianças gostaram muito da atividade desenvolvida e evidentemente serão inseridos esses conhecimentos nos contextos educacionais da escola (CURARRÁ KARAJÁ E LIMA KARAJÁ, 2012, p. 75).

[...] quando o artesão Lawari estava fazendo o behyra ele lembrou de uma história que fala do behyra. Após 
ANDRÉ MARQUES DO NASCIMENTO - Desafios à elaboração curricular para a educação...

tudo pronto, as crianças fizeram uso dos artesanatos para aprenderem como são usados estes artesanatos tradicionais da Terra Indígena Xambioá (KUMARE KARAJÁ, 2011a, p. 47-48).

Neste movimento, ainda recente, mas já com impactos comunitários consideráveis, os professores e as professoras indígenas karajá xambioá e guarani têm exercido um importante papel não só de articuladores/as dessas ações vinculadas às suas culturas, como também de agentes críticos privilegiados na interlocução entre sua sociedade e a sociedade não indígena, entre seus conhecimentos ancestrais e os conhecimentos não indígenas necessários para essa interlocução.

É neste movimento pendular entre as mudanças e a retomada, entre transformações e permanências, ou mesmo na reconstrução do próprio e do exógeno, que têm se dado as reflexões em torno do currículo para as escolas da Terra Indígena Xambioá.

Dialeticamente, são precisamente as dimensões das mudanças ocasionadas pela interação, jamais pacífica ou harmoniosa, com o não indígena, e do retorno ao próprio, sem uma visão idílica ou romantizada de passado, que têm fundamentado as discussões, as decisões e as ações que visam à elaboração e a implementação de matrizes curriculares que sejam coerentes com as funções sociais de escola situada e com o projeto maior de descolonização, como ressalta Kurikalá Karajá:

o objetivo desta nova proposta é uma educação indígena democrática, de manutenção da diferença sem a sua subalternização. Este ensino deve ter como objetivo descolonizar as populações indígenas e seus conhecimentos, que sofrem debaixo da invasão linguística e da imposição do conhecimento nãoindígena (KURIKALÁ KARAJÁ, 2012, p. 3).

Neste sentido, para além da motivação para a resistência inerente ao povo Karajá Xambioá e também ao povo Guarani, as atividades de Estágio Pedagógico desenvolvidas pelos professores e professoras indígenas no âmbito da Licenciatura Intercultural da UFG têm contribuído sobremaneira para a emergência de alternativas viáveis ao enfrentamento dos obstáculos que se impõem na ruptura de uma longa 
ANDRÉ MARQUES DO NASCIMENTO - Desafios à elaboração curricular para a educação...

tradição escolar opressora, excludente e colonizadora destinadas aos seus povos, como aos povos indígenas brasileiros de forma geral.

Na seção seguinte, buscarei apresentar sucintamente como estas atividades de Estágio Pedagógico, já mencionadas, têm sido desenvolvidas e as suas contribuições diretas à proposta curricular para a escola indígena karajá xambioá.

\section{Experiências didático-pedagógicas e epistemológicas nas atividades de Estágio Pedagógico}

As atividades do Estágio Pedagógico da Licenciatura Intercultural da UFG, como mencionado, são o locus privilegiado de reflexões e práticas concernentes às dimensões didático-pedagógicas da práxis docente indígena. Estas atividades visam, primordialmente, ao desenvolvimento de bases conceptuais, epistemológicas e metodológicas que fundamentem a educação escolar indígena, em coerência com os interesses das comunidades onde se situam as escolas, sob a perspectiva dos princípios pedagógicos da interculturalidade e da transdisciplinaridade, tendo como fundamento básico e inequívoco as ontologias indígenas, assim como a proposta de diálogo com as formas de conhecimentos não indígenas.

Neste contexto, conforme Albó (2005), um dos pensadores referenciais das relações interculturais na América Latina, a interculturalidade pode ser definida como qualquer relação entre pessoas ou grupos sociais de culturas diferentes e, por extensão, diz respeito às atitudes de pessoas e grupos de uma cultura em relação a elementos de outra cultura. De acordo com o autor, as relações interculturais são negativas quando levam à destruição, assimilação ou diminuição do que é diferente; e positivas quando levam ao respeito e ao enriquecimento mútuo, a partir de um intercâmbio enriquecedor.

Tubino (2004), também a partir do contexto latino-americano, adverte, contudo, que o conceito de interculturalidade deve ser tomado desde uma perspectiva crítica, especialmente num contexto de luta por direitos historicamente negados, como é o caso nas relações estabelecidas entre os diversos povos indígenas brasileiros com a 
ANDRÉ MARQUES DO NASCIMENTO - Desafios à elaboração curricular para a educação...

sociedade não indígena. Esta postura crítica em relação ao reconhecimento das relações entre diferentes culturas é necessária, em suas palavras, porque

as diferenças entre o interculturalismo funcional e o interculturalismo crítico são substantivas. $O$ ponto de partida e a intencionalidade do interculturalismo crítico são radicalmente diferentes. Enquanto 0 interculturalismo neoliberal busca promover o diálogo sem tocar nas causas da assimetria cultural, o interculturalismo crítico busca suprimi-las. [...] Para tornar o diálogo real, há que se começar por visibilizar as causas do não diálogo. Em outras palavras, há que se começar por identificar e tomar consciência das causas contextuais de sua inoperância. Há que se começar por recuperar a memória dos excluídos, por visibilizar os conflitos interculturais do presente como expressão de uma violência estrutural mais profunda, gestada ao longo de uma história de desencontros e postergações injustas (TUBINO, 2004, p. 6-7, tradução minha).

De maneira geral, no contexto de trabalho do comitê Karajá Xambioá e Guarani, a interculturalidade tem se tornado uma importante concepção para a compreensão sócio-histórica das relações entre indígenas e não indígenas, bem como de suas consequências contemporâneas, além de seus impactos na educação escolar, como reflete Lima Guarani:

Na comunidade Karajá Xambioá, a interculturalidade passou a ser impulsionada com mais vigor, mais ou menos, por volta dos anos de 1950. No início, esta situação de interculturalidade teve uma representatividade bastante negativa, porque muitas das vezes, uma cultura entrava em conflito com a outra na tentativa de impor hegemonia. A cultura nãoindígena, desde quando entrou na aldeia, foi matando a cultura indígena, até o ponto de se tornar dominante, como é a situação de hoje. Entretanto, na atualidade, sabemos que viver sem a interculturalidade é impossível. A gente só tem é que saber como lidar com ela. É sempre bom conhecer o conhecimento do próximo, respeitar os saberes do outro, mas valorizar, principalmente, o que é nosso. Até hoje a interculturalidade pode trazer algo negativo para as comunidades indígenas, mas não se deve ocultar que 
ANDRÉ MARQUES DO NASCIMENTO - Desafios à elaboração curricular para a educação...

ela também é algo muito importante na construção de novos saberes (LIMA GUARANI, 2012, p. 5).

A transdisciplinaridade, por sua vez, segundo Nicolescu (2005), como o próprio prefixo 'trans' indica, "diz respeito àquilo que está ao mesmo tempo entre as disciplinas, através das diferentes disciplinas e além de qualquer disciplina" e "seu objetivo é a compreensão do mundo presente, para o qual um dos imperativos é a unidade do conhecimento" (NICOLESCU, 2005, p. 53). Segundo Paul,

a abordagem transdisciplinar se apreende então como uma nova organização do conhecimento, como uma nova hermenêutica das colocações em relação, como um processo epistemológico e metodológico de resolução de dados complexos e contraditórios situando as ligações no interior de um sistema total, global e hierarquizado sem fronteiras estáveis entre as disciplinas, incluindo a ordem e a desordem, o sabido e o não sabido, a racionalidade e a imaginação, o consciente e o inconsciente, 0 formal e o informal (PAUL apud SOMMERMAN, 2006, p. 45).

Assim, enquanto abordagem epistemológica,

a transdisciplinaridade é o questionamento do logocentrismo e da configuração paradigmática do conhecimento, o qual erradicou da ciência normal todo saber não científico como externo e estranho, como patológico, como 'não-conhecimento'; é a transgressão da disciplinaridade, do saber codificado para aprender, 'coisificar', objetivar o real (LEFF apud SOMMERMAN, 2006, p. 31).

Assim, como uma nova forma de conceber, de produzir e organizar o conhecimento, a transdisciplinaridade se apresenta como uma alternativa viável à fragmentação disciplinar cada vez mais radical, característica inequívoca da forma de produzir e transmitir conhecimento no "sistema-mundo moderno/colonial capitalista/patriarcal" (GROSFOGUEL, 2007, p. 213) orientada por paradigmas eurocêntricos, uma vez que se propõe a "articular a multirreferencialidade e a multidimensionalidade do ser humano e do mundo" (MELLO, BARROS e SOMMERMAN, 2002, p.10) através da integração de diversas áreas do saber e da comunicação entre os 
ANDRÉ MARQUES DO NASCIMENTO - Desafios à elaboração curricular para a educação...

sujeitos produtores de diferentes saberes (ALMEIDA FILHO, 2005), originados, eu acrescentaria, inclusive, em diferentes culturas.

O processo colonial gerador da maior parte dos contextos interculturais atuais e, principalmente, de suas consequências negativas, que afetam mais de três quartos da população mundial (ASHCROFT, GRIFFITHS e TIFFIN, 2002), são, conforme Brandão (2008), uma das principais evidências da necessidade de se buscar outros sentidos para o saber que questionem a falácia do progresso técnico. Para o autor, uma das razões da transdisciplinaridade em nossos dias é a própria

evidência da barbárie, o contrapelo daquele ideal civilizatório que se imiscuía em torno da ideia de progresso, progresso este que nunca chega a grande parte do mundo. A proximidade da destruição, miséria e hecatombe total, da cultura ao ambiente, tornou-se por demais evidente, principalmente nas regiões periféricas e marginais do Ocidente (BRANDÃO, 2008, p. 23).

Segundo Brandão, a transdisciplinaridade se apresenta, assim, como

uma interação e uma abertura das disciplinas tanto às outras disciplinas quanto ao "indisciplinado", conformando-se e contagiando-se reciprocamente, a começar pelo que lhes é marginal ou periférico. [...] $A$ transdisciplinaridade ocorre quando há uma modificação epistemológica nova para a compreensão dos fenômenos, diálogos com conhecimentos considerados não científicos e com diferentes níveis do sujeito e da realidade (BRANDÃO, 2008, p. 27-28).

Tendo em vista que um dos grandes problemas relacionados à educação na contemporaneidade é a excessiva fragmentação e a compartimentalização do conhecimento, refletida nos currículos e na práxis educativa, assim como a consideração exclusiva do conhecimento anglo-eurocêntrico, estrategicamente alçado à categoria de universal, a opção pela prática transdisciplinar, no âmbito da LI-UFG, se apresenta como uma alternativa viável num contexto em que busca-se fazer dialogar criticamente os conhecimentos produzidos pela sociedade não indígena e entre esses e os conhecimentos produzidos em/por diversas culturas indígenas, a partir de outras concepções de mundo e, mesmo, 
ANDRÉ MARQUES DO NASCIMENTO - Desafios à elaboração curricular para a educação...

de outras concepções e formas de produção e transmissão de conhecimento.

Neste sentido, Santos (2008) enfatiza que é a perspectiva intercultural que permite ainda "o reconhecimento da existência de sistemas de saberes plurais, alternativos à ciência moderna ou que com ela se articulam em novas configurações de conhecimentos" (SANTOS, 2008 , p. 152), fenômeno que o autor concebe como uma "ecologia de saberes", definida como "um conjunto de epistemologias que partem da diversidade e da globalização contra-hegemônicas e pretendem contribuir para as credibilizar e fortalecer" (SANTOS, 2008, p. 154).

A meu ver, a contribuição destas concepções para a reflexão em torno do currículo das escolas indígenas é a possibilidade que se emerge de promover meios de abarcar a ecologia de saberes provenientes das relações interculturais nas quais atuam os povos indígenas brasileiros contemporâneos, tendo como ponto de partida os conhecimentos indígenas, mas a fim de que se construa

um modo verdadeiramente dialógico de engajamento
permanente, articulando as estruturas do saber
moderno/científico/ocidental às formações
nativas/locais/tradicionais de conhecimento. O desafio
é, pois, de luta contra uma monocultura do saber, não
apenas na teoria, mas como uma prática constante do
processo de estudo, de pesquisa-ação (SANTOS, 2008,
p. 154).

A busca pela implementação de uma ecologia de saberes, considerando-se as relações entre os povos indígenas e a sociedade não indígena no Brasil, assume, antes de tudo, um caráter de descolonização, dentre outras, das formas de conhecimentos não ocidentais, historicamente subjugadas e exterminadas, como analisa Kumare Karajá:

A partir da colonização no Brasil, os povos indígenas foram obrigados a se adaptarem à sociedade de origem europeia, sendo seus conhecimentos próprios usados apenas para a expansão colonial no território brasileiro. Ainda hoje, os conhecimentos indígenas não são reconhecidos pelos pesquisadores não-indígenas, quando são, é apenas para favorecerem a si próprios, pois continuam a serem vistos e valorizados apenas os 
ANDRÉ MARQUES DO NASCIMENTO - Desafios à elaboração curricular para a educação...

conhecimentos ocidentais. Como parte do processo colonial, as escolas dirigidas aos indígenas foram concebidas como integracionistas e assimilacionistas, ministradas por organizações religiosas, como a dos jesuítas, e posteriormente com 0 apoio do regime militar, assegurada pela instituição do SPI, Serviço de Proteção ao Índio. Seus objetivos sempre foram desenvolver os conhecimentos eurocêntricos, fazendo os conhecimentos indígenas serem extintos. As práticas tradicionais indígenas não poderiam ser executadas em suas aldeias de origem e nem em outros locais (KUMARE KARAJÁ, 2012, p. 1-2).

Fundamentadas, assim, por estes princípios, as experiências geradas e vivenciadas pelos professores e professoras indígenas karajá xambioá e guarani, no âmbito das atividades de Estágio Pedagógico, merecem destaque em pelo menos duas dimensões principais: i) a valorização e a incorporação do conhecimento indígena em suas atividades pedagógicas, que por sua vez tornam-se intrinsecamente vinculadas ao contexto local e concreto de sua realidade e, intimamente relacionada a esta primeira dimensão; ii) a forma contextualizada $e$ crítica de abordagem dos conhecimentos indígenas e dos conhecimentos hegemônicos necessários em suas relações com as sociedades não indígenas.

A abordagem crítica e contextualizada dos conhecimentos, por sua vez, tem feito emergir temas contextualizados relevantes para suas comunidades e, por essa razão, plenamente aptos a constituírem o currículo de suas escolas, diferentemente do legado colonialista a que estiveram submetidos estes povos através da educação escolar, que separou o "escolar", ou seja, os conhecimentos de base eurocêntrica, do "não escolar", isto é, os conhecimentos indígenas, como constata Lima Guarani, ao refletir sobre suas práticas docentes no início das atividades de Estágio:

De forma geral, esses trabalhos, principalmente o primeiro, foram encarados por mim como um novo desafio, pois embora eu já tivesse alguns anos de sala de aula, percebi que vinham novas formas de transmitir os conhecimentos, pois até ali, o pouquinho de experiência que eu tinha ainda era herança do sistema de educação colonizadora, um modelo totalmente voltado para a organização disciplinar do conhecimento. 
ANDRÉ MARQUES DO NASCIMENTO - Desafios à elaboração curricular para a educação...

Um modelo de ensino que criava uma espécie de abismo muito perigoso entre a escola e a comunidade. Era como se o conhecimento de um não pudesse chegar até o outro. Todavia, com o planejamento das aulas de estágio, as janelas da escola e da aldeia se abriram umas para as outras e ambas para novos paradigmas da educação escolar indígena (LIMA GUARANI, 2012, p. 9).

Nesta direção, estes professores e professoras indígenas têm buscado partir do local, do próprio, para, a partir daí, estabelecerem novas relações com outras formas de conhecimento e, assim, alcançarem formas críticas de compreensão do mundo, mais gerais, holísticas e complexas, sobre as quais, nós, não indígenas imbuídos/as pela lógica do pesamento ocidental de matriz eurocêntrica, ainda temos muito o que aprender com eles e elas. Nesta busca pela valorização do local, há, inevitavelmente, a necessidade prememente da compreensão do lugar de pertencimento como a principal fonte para o conhecimento válido, pois, conforme constata Orr,

uma boa parte do que é tido como conhecimento é pouco mais do que uma pilha de abstrações, desvinculadas da experiência concreta, dos problemas reais e dos lugares onde vivemos e trabalhamos. Nesse sentido, ele é utópico, o que significa literalmente 'lugar nenhum' (ORR, 2006, p. 117).

Além disso, Orr destaca que

o estudo do lugar é relevante para o problema da superespecialização, que vem sendo chamado de doença terminal da civilização contemporânea. Esse problema é seguramente debilitante para o intelecto individual. Ele [o remédio para esse problema] só pode ser alcançado pela redefinição dos propósitos da educação no sentido de promover a diversidade do pensamento e um entendimento mais amplo das suas inter-relações. Os lugares são laboratórios de diversidade e complexidade, misturando as funções sociais e os processo naturais. O lugar tem uma história humana e um passado geológico; ele é parte de um ecossitema com uma variedade de microssitemas, é uma paisagem com uma flora e uma fauna particulares. Os seus habitantes fazem parte de uma ordem social, econômica e política: eles importam ou exportam 
ANDRÉ MARQUES DO NASCIMENTO - Desafios à elaboração curricular para a educação...

fontes de energia, água e detritos; estão ligados a outros lugares por incontáveis vínculos. Não se pode entender um lugar da perspectiva de uma única disciplina ou especialização. Ele só pode ser entendido nos seus próprios termos como um mosaico complexo de fenômenos e problemas. A sala de aula e o laboratório interno são ambientes ideais para se reduzir a realidade de maneira a enfocar as coisas pequenas. 0 estudo do lugar, ao contrário, nos permite ampliar o foco para examinar as relações entre as disciplinas e estender a nossa percepção do tempo (ORR, 2006, p. 120-121).

Considerando as reflexões acima e tomando-se como referência a compreensão dos professores e professoras indígenas karajá xambioá e guarani, acadêmicos do curso de Licenciatura Intercultural da Universidade Federal de Goiás, pode-se perceber como a preocupação com as bases de conhecimentos indígenas locais e suas relações com conhecimentos de "outros locais" se manifestam em suas reflexões e práticas pedagógicas. Isto fica visível e adquire extrema relevância nas palavras dos próprios professores e professoras karajá xambioá e guarani, ao apresentarem suas experiências no Estágio Pedagógico. Wajurema Karajá (2012), em sua análise, constata que

o estágio pedagógico constitui uma parte importante do processo de formação docente, pois visa ao desenvolvimento de competências interculturais dos licenciandos no âmbito das práticas pedagógicas de sala de aula, numa perspectiva de aperfeiçoamento profissional, nos domínios científicos, didáticos, pedagógicos e políticos. Espero, assim, que minha experiência de Estágio possa ajuda nesta construção de novas bases pedagógicas voltadas diretamente para nossas realidades, em forma de conscientização ambiental, cultural e social, para que assim o meu povo possa valorizar mais ainda os seus conhecimentos e cultura tradicionais, da mesma forma que possa conhecer e analisar criticamente os conhecimentos nãoindígenas, porque de uma forma ou de outra, esses estão contribuindo conosco, ou seja, com a nossa sociedade, para que também possamos conhecer outras culturas (WAJUREMA KARAJÁ, 2012, p. 03).

Nas reflexões de Kumare Karajá (2012), as atividades desenvolvidas no âmbito do Estágio Pedagógico contribuíram, também, 
ANDRÉ MARQUES DO NASCIMENTO - Desafios à elaboração curricular para a educação...

para o reconhecimento de dimensões que a escola indígena até hoje tem negligenciado, principalmente as formas e os processos próprios de conhecimentos, ensino e aprendizagem indígenas, aspectos fundamentais para as reflexões sobre educação escolar indígena. Em sua análise,

geralmente, os não-indígenas têm o hábito de passar seu conhecimento através da escrita, usando livro didático feito por outra pessoa, sendo copiado tudo o que o outro fez, principalmente a história do seu povo. A escola é um campo de transmissão de conhecimento formal para os ocidentais. Tudo que eles adquirem é através de pesquisa, pegando informação daquilo que eles acham interessante para sua formação. Os povos indígenas têm outros contextos totalmente diferentes. A transmissão dos saberes é feita de geração em geração, no ensino e aprendizagem fora da escola, através de histórias, músicas, mitos, cânticos, danças e outras atividades. Toda atividade é executada na prática, suas técnicas são adquiridas no cotidiano. A escola é apenas um instrumento para ajudar as crianças indígenas a organizarem a escrita em língua indígena e em língua portuguesa. Devido à colonização em nosso país ter bastante tempo, são encontradas comunidades indígenas bem focalizadas em outros tipos de transmissão de conhecimento, mesmo assim, continuam preservando seus costumes próprios de vida em suas sociedades. Mesmo com todas as pressões aos povos indígenas pelos ocidentais, ainda é enorme o conjunto de epistemologia originária no Brasil (KUMARE KARAJÁ, 2012, p. 3).

Em suas atividades de Estágio, estes professores e professoras indígenas têm buscado respaldo epistemológico e alternativas pedagógicas nas formas de conhecimentos indígenas próprios de suas culturas, buscando a constituição de uma base de conhecimentos local, para, posteriormente, abordarem conhecimentos não indígenas que, na contemporaneidade das relações interculturais, assumem significância para seus povos. Neste sentido, a análise de Wajurema Karajá (2012) torna-se bastante representativa da trajetória da práxis docentes dos professores e professoras indígenas karajá xambioá e guarani percorrida durante sua formação:

Assim que iniciamos a parte específica do curso de

Espaço Ameríndio, Porto Alegre, v. 7, n. 1, p. 95-145, jan./jun. 2013. 
ANDRÉ MARQUES DO NASCIMENTO - Desafios à elaboração curricular para a educação...

Licenciatura Intercultural, escolhi como meu tema de trabalho de Estágio "Pinturas corporais de nosso povo". Trabalhei este tema nos estágios I, II e III. No Estágio I, abordei especificamente a "Pintura do Jabuti". No Estágio II foi a "Pintura da Jibóia" e no III, a "Pintura do Rastro do Papagaio". Resolvi trabalhar com este tema, porque é um aspecto muito importante para nós e para nossa cultura, porque muitos de nossos alunos e membros de nossas comunidades não conhecem os significados das pinturas, quem pode usar e quem não pode e muitos já nem querem mais usá-las. Assim, para valorizar a nossa cultura e os nossos conhecimentos, estou trabalhando nas escolas e no cotidiano da aldeia com a pintura corporal, incentivando as crianças e os jovens, os adultos e os mais velhos a usarem a pintura no dia a dia, para que nossa cultura se fortaleça. O objetivo das atividades de estágio são, assim, que os alunos e alguns membros da comunidade conheçam o significado de cada pintura corporal de nosso povo, para que também possa ajudar futuramente em suas pesquisas escolares e acadêmicas (WAJUREMA KARAJÁ, 2012, p. 3-4).

Ao abordar este mesmo tema de trabalho pedagógico, Kumare Karajá (2012) faz a seguinte análise do contexto sócio-histórico de suas decisões:

A escolha deste tema contextual para as aulas se deu porque nós, Karajá Xambioá, devido aos contatos constantes com a sociedade não-indígena que vem ocorrendo desde a colonização até o atual momento, sofremos grandes impactos e mudanças nos aspectos culturais, sendo um desses aspectos o uso da pintura corporal. Para nós, a pintura tem a representabilidade dos animais e dos momentos cerimoniais, sendo utilizadas tanto nas crianças como nos adultos, fazendo também o uso conforme o gênero, masculino ou feminino. Com a perda dos anciãos, os jovens não vinham praticando as pinturas corporais que, mais recentemente, já têm sido usadas, mas a maioria dos jovens não sabe seus significados. Como educador, posso passar estes significados através da consulta com os mais velhos (WAJUREMA KARAJÁ, 2012, p. 4-5).

Sobre a abordagem contextualizada de sua prática pedagógica, o autor nos ensina:

Ao trabalhar com a concepção de temas contextuais, fiz

Espaço Ameríndio, Porto Alegre, v. 7, n. 1, p. 95-145, jan./jun. 2013. 
ANDRÉ MARQUES DO NASCIMENTO - Desafios à elaboração curricular para a educação...

com que os alunos despertassem interesse em vários conhecimentos, buscando abranger áreas como a matemática, línguas, histórias, ciências e geografia em um só momento, para construir junto o conhecimento dos dois mundos em que nós vivemos. Além disso, o trabalho com a pintura corporal se relaciona com a sustentabilidade cultural da comunidade, e ajuda bastante na revitalização dos aspectos culturais onde os alunos se tornam os protagonistas deste trabalho (KUMARE KARAJÁ, 2012, p. 5).

No que concerne especificamente à elaboração curricular, Kumare Karajá (2012) faz a seguinte análise a partir das experiências de Estágio:

A partir das experiências desenvolvidas nos Estágios, minha reflexão pedagógica mudou totalmente, o que tem favorecido novas possibilidades de diretrizes curriculares para as escolas Karajá Xambioá, que acolham a diversidade cultural e se paute na sustentabilidade deste povo, que sofreu desde a chegada dos colonizadores em seu território de origem. As aulas e as experiências adquiridas podem se tornar um importante instrumento que deve enfatizar a realidades das comunidades, pautado na realidade sociolinguística do povo Karajá Xambioá, suas culturas que foram fragmentadas com as fronteiras impostas e as invasões linguísticas da sociedade não-indígena, tornando a educação indígena diferenciada, respeitando as especificidades que ainda são preservadas (KUMARE KARAJÁ, 2012, p. 10-11).

Krumare Karajá (2012), por sua vez, abordou aspectos da sustentabilidade dos recursos ambientais de seu povo em uma das atividades de Estágio, contextualizando os conhecimentos próprios dos Karajá Xambioá sobre os peixes, bem como os problemas contemporâneos que envolvem a extinção deste recurso vital para a sua sobrevivência cultural e física. Conforme suas palavras,

os peixes sempre fizeram parte da cultura do povo Karajá Xambioá. Existem peixes que têm suas histórias contadas pelos Xambioá e mesmo nos cantos e eles sempre se alimentam dos peixes no seu dia a dia e nas festas tradicionais, servindo, assim, como um elemento importante na sustentabilidade cultural e econômica para nossa comunidade, que vive às margens do rio Araguaia. Esta foi a minha preocupação, porque nós Karajá Xambioá sobrevivemos mais dos peixes no 
ANDRÉ MARQUES DO NASCIMENTO - Desafios à elaboração curricular para a educação...

nosso dia a dia, que também são importantes nas grandes festas tradicionais. Durante 0 estágio realizado, tive bastante aproveitamento, porque não só os alunos aprenderam, como também a própria comunidade. Assim, as aulas do Estágio I, no primeiro semestre de 2009, foram sobre a extinção dos peixes. No meu ponto de vista, as atividades de Estágio foram muito importantes, porque os indígenas já começaram a se preocupar com o desaparecimento de várias espécies de peixes. Hoje eles pescam só os peixes que ainda não estão em extinção. Isto para nós professores já é um bom começo. Os indígenas quase já não pescam na nossa reserva, pescam quase sempre fora da reserva para conservarem os peixes de nossa área. Isto já é um grande avanço para a preservação dos peixes da região (KRUMARE KARAJÁ, 2012, p. 2).

O autor constata ainda:

Nas minhas aulas, todos os alunos participaram. Eles estavam bastante envolvidos, porque era um tema muito importante para eles, porque cada um conhecia um tipo de peixe. Eu achei que os alunos gostaram bastante, pois foi uma aula diferente dos nãoindígenas. Por isso eles acharam muito boas as aulas, porque era sobre os peixes de sua própria região. Na minha concepção, foi importante trabalhar com as duas línguas, mesmo que apenas nos nomes dos peixes, pois na minha comunidade a língua portuguesa é dominante e temos de começar aos poucos o trabalho com a língua materna. Durante essas aulas, a gente procurou mais os anciãos da aldeia para fazermos pesquisas, porque eles conhecem cada espécie de peixes que está em extinção e os que ainda existem na nossa região. Não apenas nós professores estamos preocupados, mas também a nossa própria comunidade está envolvida na preservação dos peixes. Durante minhas aulas, algumas pessoas da comunidade estavam presentes e algumas apresentaram os cantos indígenas no encerramento destas aulas (KRUMARE KARAJÁ, 2012, p. 3).

Foi também contextualizando o conhecimento sobre o meio ambiente local que este professor abordou conhecimentos indígenas e não indígenas sobre a linguagem e sobre a linguagem matemática, desenvolvendo formas pedagógicas de trabalho com o letramento e o numeramento em uma turma em alfabetização:

Espaço Ameríndio, Porto Alegre, v. 7, n. 1, p. 95-145, jan./jun. 2013. 
ANDRÉ MARQUES DO NASCIMENTO - Desafios à elaboração curricular para a educação...

iniciei os trabalhos explicando para os alunos das $1^{\text {a }} \mathrm{e}$ 20 séries que com os elementos da natureza, como os caroços das frutas, podemos aprender a contar e mesmo a fazer contas. Depois das explicações, pedi para que cada aluno desenhasse as frutas sobre as quais tínhamos conversado e cada aluno desenhou e pintou o seu trabalho. Senti que os alunos gostaram bastante deste trabalho, que aconteceu dentro e fora da sala de aula. Depois, pedi que cada aluno desenhasse dois muricis e cada aluno fez isto. Depois, recolhi os trabalhos e mostrei que cada figura representava uma quantidade e que cada figura desenhada podia ser representada por um número, porque tinha alunos que não conheciam os números. Assim, através dos desenhos de elementos de nossa natureza, eles começaram a aprender sobre os números. Pedi, então, que cada aluno falasse sobre o seu desenho e qual era o número que estava sendo representado no desenho. Depois, pedi para que cada aluno fosse ao meio da aldeia e juntasse cinco pedrinhas para eu ver se eles estavam compreendendo e eles mostraram que estavam compreendendo, porque cada um trouxe para a sala a quantidade certa de pedrinhas. Cada criança contou suas pedrinhas, todos corretamente (KRUMARE KARAJÁ, 2012, p. 4-5).

Kurikalá Karajá, também abordando a preservação dos peixes da Terra Indígena Xambioá, buscou na ancestralidade do conhecimento do povo Iny recursos para ensinar as crianças sobre a importância da preservação dos peixes, como também os saberes advindos da mitologia e das práticas comunicativas indígenas. Em seu relato, o autor explica:

No Estágio II, no segundo semestre de 2009, trabalhei o tema "Mitos do povo Karajá", através do mito "O homem que transformava os humanos em pássaros e caças". Este mito traz bastantes ensinamentos sobre o respeito na pescaria dos nossos ancestrais, para que não seja esquecido este tipo de pescaria pelos nossos filhos. Esta atividade foi realizada para que as crianças saibam o mito do nosso povo, para que esta tradição não morra no meio do caminho $[\ldots]$. Neste tema, foi ressaltada a importância da preservação da língua materna e da cultura do povo Xambioá (KURIKALÁ KARAJÁ, 2012, p. 5). 
ANDRÉ MARQUES DO NASCIMENTO - Desafios à elaboração curricular para a educação...

Em suas experiências durante o Estágio, o autor destaca ainda a importância do envolvimento comunitário nas atividades e as novas possibilidades pedagógicas que emergem do trabalho fora da sala de aula, o que fortalece a perspectiva de conhecer o próprio lugar:

\begin{abstract}
Este tema foi escolhido por causa da importância dos peixes para o povo Xambioá, pois serve de sustentabilidade para as famílias das comunidades, além de ter importante papel na cosmovisão deste povo, como apresenta sua mitologia, por exemplo. Por esta razão, nos preocupamos com os peixes que estão em extinção e através destas atividades de Estágio, a comunidade pode nos ajudar a preservar os peixes que estão acabando, através da conscientização da população, para que no futuro os peixes continuem sendo fonte de sustentabilidade da população. Para o trabalho com este tema, foram realizadas pesquisas com os anciãos da aldeia sobre os peixes que existiam. Segundo eles, antes havia uma diversidade e uma quantidade bem maiores de peixes, que hoje não se encontram mais. Esta pesquisa foi feita na beira do rio Araguaia, mostrando a dificuldade de pegar os peixes que estão em extinção (KURIKALÁ KARAJÁ, 2012, p. $6)$.
\end{abstract}

Neste mesmo sentido, Lima Guarani enfatiza, em sua prática docente no Estágio pautada nos conhecimentos indígenas locais, a importância do fortalecimento dos vínculos com os anciãos e anciãs das comunidades de Xambioá, pois trata-se dos/as mantenedores/as do conhecimento ancestral deste povo. Assim o professor relata sua experiência:

Para eu desenvolver estes trabalhos sem ter domínio dos temas tive que me dirigir até um ancião indígena no intuito de ter uma boa conversa, um diálogo longo com bastante atenção. Naquele momento minha missão era de aprender e não de ensinar. A pessoa com quem conversei no primeiro momento foi o Senhor Josué Txebuaré Karajá, cacique da Aldeia Hawà-Tỹmara (Nova Morada). Foi ele quem me explicou acerca dos conhecimentos culturais e, sobretudo, sobre a estética das pinturas corporais, que era pauta daquela conversa (LIMA GUARANI, 2012, p. 10).

Este professor percebeu, ainda, em suas práticas pedagógicas, a 
ANDRÉ MARQUES DO NASCIMENTO - Desafios à elaboração curricular para a educação...

importância da ampliação dos contextos de ensino aprendizagem para além da sala de aula e da escola, ao abordar os recursos naturais necessários para a realização da Pintura Corporal dos Karajá Xambioá:

\begin{abstract}
E como o trabalho é contínuo, foram realizadas em uma outra etapa atividades extraclasse para que os alunos fossem levados direto ao encontro com a flora de nossa região. Ali, pude observar a ansiedade e a curiosidade que cada um despertou. Estavam mesmo animados e pareciam estar saindo de uma prisão, situação que me sensibilizou. $\mathrm{Na}$ volta, trouxeram muitas frutas de jenipapo. Assim aconteceu também na panha do urucum, feita em um outro dia (LIMA GUARANI, 2012, p. 12).
\end{abstract}

As experiências dos professores e professoras indígenas até agora apresentadas podem sugerir, numa leitura inicial ou desinformada, o privilégio de temas de trabalho exclusivamente indígenas, ou como temos nomeado no âmbito da Licenciatura Intercultural, temas contextuais intraculturais. Neste sentido, cabe esclarecer que desde o início das atividades de Estágio Pedagógico foi uma tendência inicial geral dos acadêmicos e acadêmicas indígenas de todos os povos a seleção de temas prioritariamente pertencentes às suas culturas, muito embora as orientações por parte dos professores e professoras orientadores/as tenha sido a da perspectiva dialógica entre as formas de conhecimentos indígenas e não indígenas.

No decorrer de nossos trabalhos, entretanto, este movimento geral em direção ao conhecimento próprio de suas culturas tornou-se uma clara evidência da necessidade premente de valorização destas formas de conhecimento historicamente silenciadas e sucumbidas diante das formas de conhecimentos não indígenas hegemônicos que sempre e exclusivamente dominaram a educação escolar indígena (e também a não indígena!). Passamos a compreender, então, que se tratava mais de um imperativo histórico salientado por esses professores e professoras indígenas e uma condição prévia em direção a uma educação intercultural crítica em sua dimensão descolonizante, de fato.

Esta direção assumida pelos acadêmicos e acadêmicas indígenas não deve ser, assim, interpretada como uma busca pela permanência na 
ANDRÉ MARQUES DO NASCIMENTO - Desafios à elaboração curricular para a educação...

"zona de conforto" do que é próprio e nem como a negligência da importância de aspectos do conhecimento não indígena. Informa esta minha interpretação a interação no comitê Karajá Xambioá e Guarani, onde pude perceber que, para este contexto específico, a busca pelos conhecimentos indígenas e sua abordagem em termos didáticopedagógicos, em muitas ocasiões, impôs-se como uma difícil tarefa, como ilustra a autorreflexão apresentada por Lima Guarani:

Esta nova proposta de Estágio Pedagógico veio com a função de abordar os conhecimentos próprios indígenas e transmiti-los aos alunos, de modo que eles passassem a valorizar as suas raízes, seus costumes como um todo. Foi aí que eu entendi que realmente eu teria mesmo que estagiar, porque aulas daquela natureza eu nunca tinha dado. E assim tive muita dificuldade, porque desta vez, ao contrário das outras, eu não dominava o tema. Tive que ir atrás dos mais velhos para aprender primeiro com eles, para depois procurar formas de repassar esses conhecimentos para os alunos. Teve momentos em que eu tive que convidar alguns dos mais velhos para virem à sala de aula, porque não me achei com grandeza suficiente para falar dos costumes tradicionais. Assim, só eles poderiam desenvolver, como realmente desenvolveram muitíssimo bem, os temas propostos (LIMA GUARANI, 2012, p. 3).

Da mesma forma, é bastante óbvia para os professores e professoras indígenas karajá xambioá e guarani a importância de conhecimentos da cultura hegemônica e de sua abordagem na educação escolar, não apenas por ser uma opção conceptual do curso da LI-UFG, mas pelas próprias contingências de suas interações com as sociedades não indígenas e pelas diversas formas de opressão nelas originadas. Em outras palavras, pelas próprias condições de sua sobrevivência. A análise de Kurikalá Karajá (2012) embasa esta afirmação:

A educação escolar indígena atualmente deve fazer dialogar dois tipos de conhecimentos importantes para os povos indígenas. Muitos destes saberes são milenares dos nossos ancestrais e outros são interculturais, que se juntaram depois de 500 anos no meio de nossa língua e de nossa cultura. Assim, além dos conhecimentos dos nossos ancestrais, também existem os conhecimentos ocidentais que são 
ANDRÉ MARQUES DO NASCIMENTO - Desafios à elaboração curricular para a educação...

relevantes, como a língua portuguesa, que serve como defesa perante grandes autoridades ou para o diálogo com não-indígenas. Nas experiências desenvolvidas através das atividades de Estágio, aprendemos muitas coisas que não sabíamos em nossa caminhada como professores. Por isto, o Estágio se torna muito importante, pois nos incentiva a conhecer muito mais os saberes de nossos ancestrais e alcançar o que estava esquecido pelos jovens, além de refletir sobre os conhecimentos dos não-indígenas (KURIKALÁ KARAJÁ, 2012, p. 1).

De toda forma, temas de trabalho interculturalmente contextualizados têm sido abordados por estes professores e professoras indígenas e indicado mais uma caraterística importante imputada à educação escolar, a significância destes conhecimentos para a vida real e situada das comunidades indígenas. Neste sentido, os professores e professoras indígenas karajá xambioá e guarani têm problematizado temas que envolvem as consequências ambientais, culturais, políticas e econômicas de suas relações históricas com a sociedade não indígena, dando indícios de como o conhecimento não indígena deve ser abordado.

Os relatos abaixo ilustram este direcionamento, como na abordagem da "Formação do território brasileiro", em que Kumare Karajá problematiza a historiografia não indígena, branca, universalizante e excludente, ao apresentar aos seus alunos e alunas as consequências dos processos envolvidos nesta dinâmica para os povos indígenas brasileiros e, principalmente, para o povo Karajá Xambioá:

Nas aulas de Estágio IV, foram trabalhadas atividades com o intuito de mostrar os processos de formação do território brasileiro. Com os alunos Karajá Xambioá do Ensino Médio, a abordagem do tema tratou do uso de estratégias para formação do império europeu. Neste contexto, mesmo os europeus tendo seus instrumentos científicos, precisaram dos conhecimentos indígenas para a expansão por todo o território brasileiro, pois seria impossível colonizar o Brasil sem contar com as técnicas dos povos indígenas nas frentes de expansão, principalmente na região da Amazônia, onde fauna e flora são bastante intensas (KUMARE KARAJÁ, 2012, p. 9). 
ANDRÉ MARQUES DO NASCIMENTO - Desafios à elaboração curricular para a educação...

Segue na mesma direção a abordagem intercultural feita por Krumare Karajá sobre o "Manejo do meio ambiente" contemporaneamente:

Iniciei minhas atividades de Estágio no CEM [Centre do Ensino Médio] Karajá Xambioá com os alunos de primeiro ano do Ensino Médio. O tema contextual das aulas foi "Manejo do meio ambiente e preservação da natureza". Primeiro, comecei explicando sobre as consequências das queimadas das florestas da nossa região, principalmente do nosso território, que todos os anos é atingido pelo fogo. Questionei os alunos sobre como nós podemos evitar essas queimadas que vêm prejudicando o meio ambiente e principalmente acabando com os animais e as aves e acabando com a saúde do próprio homem, trazendo doenças por causa da quantidade de fumaça que contamina o ar que nós respiramos. Nós indígenas vimos sofrendo muito as consequências das queimadas, pois às vezes os próprios indígenas não sabem mais como se proteger das queimadas, fazendo com que elas não atinjam as matas e as pastagens dos fazendeiros próximos. Alguns alunos falaram que nós mesmos podemos conscientizar a nossa própria comunidade a fazer aceiro, arrastão, para quando for colocar fogo nas roças, não atingir as matas, porque os principais danos ambientais observados na região de Xambioá são as grandes queimadas, que destroem as belezas da mata (KRUMARE KARAJÁ, 2012, p. 7).

Significativa, ainda, é a experiência desenvolvida por Kurikalá Karajá, ao abordar práticas comunicativas argumentativas em língua portuguesa, contextualizando-as numa situação em que elas, de fato, podem contribuir com sua comunidade:

Este tipo de texto é importante para o fortalecimento da pessoa que está representando a comunidade indígena, principalmente fora da aldeia, para que ela possa ser um bom porta-voz do seu povo. Essa palavra pode ser usada no debate oral, nos documentos para as autoridades etc. Neste trabalho, foi promovido um debate em que os alunos simularam ser o chefe do órgão ambiental e outros os pescadores, e tiveram que argumentar a favor ou contra a venda dos peixes da área Xambioá. Este debate foi importante porque os alunos viram como ocorre a destruição dos peixes de Xambioá. Então, este trabalho realizado foi relevante,

Espaço Ameríndio, Porto Alegre, v. 7, n. 1, p. 95-145, jan./jun. 2013. 
ANDRÉ MARQUES DO NASCIMENTO - Desafios à elaboração curricular para a educação...

porque precisamos defender o que é nosso. Para isto, precisamos entender e compreender as práticas de argumentação em língua portuguesa (KURIKALÁ KARAJÁ, 2012, p. 7).

Em outro trabalho desenvolvido por Lima Karajá (2010), a professora deixa clara a dimensão intercultural e a significância de seu tema de Estágio:

Pesquisei as comidas típicas do povo Karajá Xambioá. Antigamente, os Karajá Xambioá só se alimentavam com as comidas tradicionais. Eram mais saudáveis e pouco iam ao médico tratar de algumas doenças. Hoje, em nossa alimentação, quase não se usam mais as comidas tradicionais, somente a comida do tori. Em consequência disso, vieram doenças como, diabetes, pressão alta e outras doenças que não existiam no meio do povo Karajá Xambioá (LIMA KARAJÁ, 2010, p. 15).

Ou ainda em outro tema desenvolvido pela mesma professora sobre o lixo em sua aldeia, que por sinal é uma ampliação através de religações do tema mencionado anteriormente:

Hoje, devido às grandes compras feitas na cidade, o lixo tem aumentado muito, uma quantidade assustadora. O consumo de alimentos comprados no supermercado tem trazido muitas e muitas embalagens que são jogadas de qualquer jeito, a céu aberto, na comunidade. Por todo lado que a gente anda, vê o lixo espalhado, no quintal das casas, na beira do rio. Esse lixo tem causado doenças, principalmente na época da chuva. A enxurrada ajuda a espalhar as caixas de papelão, sacolas plásticas, garrafas PET, fraldas descartáveis, pontas de cigarro, camisinhas, pilhas, chicletes, tampinhas etc. As moscas e mosquitos juntam no meio desta sujeira causando grande desconforto para todos nós. Algumas pessoas pegam seu lixo e queimam, outras jogam em buracos, o resto fica espalhado pela aldeia. Esta é a situação do lixo na minha comunidade (LIMA KARAJÁ, 2011a, p. 27).

Curarrá Karajá, em um de seus trabalhos de Estágio Pedagógico, abordou o tema "Práticas curativas tradicionais", chegando à problematização das mudanças socioculturais pelas quais passou seu povo e abordando aspectos como o abuso de medicamentos 
ANDRÉ MARQUES DO NASCIMENTO - Desafios à elaboração curricular para a educação...

industrializados:

Os nossos antepassados viveram as tradições e a cultura ainda bem forte com o uso de práticas curativas e plantas medicinais. Antigamente, entre o povo Karajá Xambioá existia o pajé. Quando adoecia alguma pessoa da tribo, era levada rapidamente ao pajé para curar. Hoje, não existe mais o pajé entre o povo Karajá Xambioá e também a prática de plantas medicinais indígenas raramente é usada. O pajé não existe mais no meio do povo Karajá Xambioá, porque houve grande perda da própria cultura e também por influência do tori, homem branco. Aconteceram grandes mudanças. Inclusive quando dói a cabeça ou tem gripe e febre, não toma mais remédio tradicional, procura o posto de saúde para tomar remédios industrializados (CURARRÁ KARAJÁ, 2011, p. 25).

Faz-se importante ressaltar ainda que, de uma perspectiva transdisciplinar, muito pouco importa se os pontos de partida do trabalho sejam intraculturais ou interculturais, pois inevitavelmente estas dimensões se encontrarão em algum ponto de sua ampliação, de suas ligações e constantes religações. Esta perspectiva pode ser mais bem compreendida através das palavras de Santos (1988), que ao propor as bases para o que chamou de "ciência pós-moderna", também destacou a tendência a uma abordagem temática do conhecimento. Em suas palavras,

no paradigma emergente o conhecimento é total, tem como horizonte a totalidade universal [...]. Mas sendo total, é também local. Constitui-se em redor de temas que em dado momento são adotados por comunidades interpretativas concretas como projetos de vidas-locais, sejam eles reconstituir a história de um lugar, manter um espaço verde, construir um computador adequado às necessidades locais, fazer baixar a taxa de mortalidade infantil, inventar um novo instrumento musical, erradicar uma doença, etc., etc. A fragmentação pós-moderna não é disciplinar e sim temática. Os temas são galerias por onde os conhecimentos progridem ao encontro uns dos outros. Ao contrário do que sucede no paradigma atual, o conhecimento avança à medida que o seu objeto se amplia, ampliação que, como a da árvore, procede pela diferenciação e pelo alastramento das raízes em busca de novas e mais variadas interfaces (SANTOS, 1988, p. 
ANDRÉ MARQUES DO NASCIMENTO - Desafios à elaboração curricular para a educação...

$65)$.

Outro ponto que pode emergir conflituoso numa leitura enviesada da abordagem de aspectos culturais indígenas na escola, como os apresentados anteriormente, seria o risco da "escolarização" de conhecimentos e práticas cujos contextos originais seriam extraescolares. Dito de outra forma, os riscos de prejuízos causados pelo fato de a educação escolar assumir funções que extrapolariam seu papel, alterando a dinâmica sociocultural das comunidades indígenas ao retirar certos conhecimentos de seus contextos originários de produção e transmissão.

Em minha interpretação, este é um risco que de fato existe, mas não me parece ser o caso no contexto dos povos Karajá Xambioá e Guarani da Terra Indígena Xambioá. No contexto destes povos, pude perceber, e as percepções dos professores e professoras indígenas informam minha percepção, que muitas de suas práticas culturais e, consequentemente, os conhecimentos indígenas que delas fazem parte sofreram bruscas alterações que são sentidas como perdas pelas comunidades. A educação escolar sem dúvida contribuiu muito para estas alterações, como mencionado anteriormente, e, talvez por isso, tenha o dever de colaborar em sua revitalização, obviamente, a partir de uma nova concepção de educação escolar. Pauto-me, neste sentido, e mais uma vez, nas reflexões indígenas:

Antigamente, todas as práticas tradicionais ocorriam cotidianamente de forma simples e natural, não se precisavam de projetos à parte para isto acontecer. Hoje é completamente ao contrário. Apenas os mais velhos sabem tais hábitos e os outros que quiserem aprender têm de fazer um esforço à parte, que é o que estamos fazendo (LIMA GUARANI, 2012, p. 11).

Neste sentido, talvez mais do que entre outros povos indígenas, e refuto aqui qualquer perspectiva generalizante, a educação escolar para os povos Karajá Xambioá e Guarani deva assumir funções no sentido de fortalecimento cultural indígena ou, no mínimo, a função de ser a articuladora deste movimento, pois parece ser este um dos desejos desses povos em relação à função social da escola indígena: 
ANDRÉ MARQUES DO NASCIMENTO - Desafios à elaboração curricular para a educação...

São muitos os desafios enfrentados na atualidade pelos povos indígenas brasileiros, como os conflitos territoriais, de fronteira, quanto às suas organizações sociais, os conflitos sociolinguísticos, quanto à sua alimentação tradicional, festas e modos próprios de trabalho etc. Diante de tantos conflitos gerados pelo contato cada vez maior com a sociedade não-indígena, a escola indígena pode vir a se tornar um campo de conhecimento intercultural, tanto na transmissão como na recepção dos saberes locais e dos saberes ocidentais, visando à articulação crítica e o estímulo às sociedades indígenas para o convívio com as outras sociedades envolventes (KUMARE KARAJÁ, 2012, p. 01).

Precisamente neste ponto situa-se meu segundo argumento. Cada vez mais percebo que a educação escolar indígena não pode se pautar em decisões, lógicas ou fundamentações exógenas, seja através de quais agentes forem, instituições governamentais e não governamentais, universidades, "especialistas em indígenas" etc. etc. etc. Trata-se de decisões que devem ser tomadas pelos principais envolvidos/as. No caso de minha atuação no comitê Karajá Xambioá e Guarani, ficou muito claro para mim, desde o início de nosso trabalho, qual deveria ser meu papel, precisamente, o de aprender junto/com os professores e professoras indígenas e com seus sábios e sábias, para depois motivar suas reflexões, a fim de direcioná-las para a prática docente.

Esta postura me fez perceber que, se os temas trabalhados pelos professores e professoras indígenas, brevemente ilustrados nesta seção, não são suficientes para a elaboração de uma matriz curricular para a educação escolar básica, esses temas indicam claramente os conhecimentos que dela não podem (mais) ser excluídos.

\section{Considerações finais}

Considerando o exposto anteriormente, que não reflete nem de longe tudo o que temos aprendido mutuamente, e para além dos ganhos didático-pedagógicos advindos das experiências de Estágio Pedagógico, em caráter de síntese, considero como uma das 


\begin{abstract}
contribuições mais importantes a emergência de temas e de formas significativas de trabalho que podem contribuir com a elaboração da matriz curricular para as escolas indígenas karajá xambioá e guarani, como apresentados no Quadro 1, a seguir.
\end{abstract}

\begin{tabular}{|c|c|}
\hline \multicolumn{2}{|c|}{$\begin{array}{l}\text { TEMAS CONTEXTUAIS TRABALHADOS NO ESTÁGIO PEDAGÓGICO PELO COMITÊ } \\
\text { KARAJÁ XAMBIOÁ E GUARANI }\end{array}$} \\
\hline $\begin{array}{c}\text { TEMAS } \\
\text { CONTEXTUAIS }\end{array}$ & DESDOBRAMENTOS \\
\hline $\begin{array}{l}\text { Pintura Corporal do Povo } \\
\text { Karajá Xambioá }\end{array}$ & $\begin{array}{l}\text { Função sociocultural das pinturas corporais para o povo Karajá Xambioá; } \\
\text { Arte e estética; Dimensões geométricas; Função social da ornamentação } \\
\text { corporal em diferentes culturas indígenas e não indígenas; Recursos } \\
\text { naturais;Práticas culturais Karajá Xambioá; Hábitos alimentares tradicionais }\end{array}$ \\
\hline Peixes & $\begin{array}{l}\text { Importância dos peixes para a cultura Karajá Xambioá; Preservação dos } \\
\text { peixes da área Xambioá; Extinção dos peixes da área Xambioá; } \\
\text { Comercialização dos peixes; Práticas argumentativas; Alfabetização; } \\
\text { Mitologia Karajá Xambioá }\end{array}$ \\
\hline Água & $\begin{array}{l}\text { Importância da água para o povo Karajá Xambioá; Preservação do rio } \\
\text { Araguaia; Uso dos recursos hídricos; Formas de poluição do rio Araguaia } \\
\text { Recursos alimentares; Mudanças na manutenção dos recursos hídricos }\end{array}$ \\
\hline $\begin{array}{l}\text { Origem da vida e do } \\
\text { homem na Terra }\end{array}$ & $\begin{array}{l}\text { Teorias não indígenas da origem da vida e do ser humano; Cosmologia } \\
\text { Karajá Xambioá sobre a origem da vida e do ser humano; Mitologia Karajá } \\
\text { Xambioá }\end{array}$ \\
\hline $\begin{array}{l}\text { Formação do território } \\
\text { brasileiro }\end{array}$ & $\begin{array}{l}\text { Historiografia não indígena da formação do território; Terra e território; } \\
\text { Perspectiva indígena sobre a ocupação não indígena do território brasileiro; } \\
\text { Consequências para os povos indígenas da ocupação do território brasileiro; } \\
\text { Terras Indígenas; Colonização e colonialidade }\end{array}$ \\
\hline Manejo ambiental & $\begin{array}{l}\text { Formas de manejo ambiental; Impactos ambientais: queimadas; Formas } \\
\text { indígenas de manejo ambiental; Doenças causadas pelos danos ambientais }\end{array}$ \\
\hline Meio ambiente & Numeramento e letramento; Educação ambiental \\
\hline $\begin{array}{l}\text { Hábitos alimentares } \\
\text { tradicionais do povo } \\
\text { Karajá Xambioá }\end{array}$ & $\begin{array}{l}\text { Comidas típicas; Fontes de alimentos tradicionais; Preservação do meio } \\
\text { ambiente; Mudanças nos hábitos alimentares; Doenças causadas pelas } \\
\text { mudanças nos hábitos alimentares; Formas de produção e consumo dos } \\
\text { alimentos; Potencial calórico dos alimentos; Roças; Sistema de mutirão } \\
\text { Trabalho comunitário; Fauna e flora; Peixes }\end{array}$ \\
\hline Roças de toco & $\begin{array}{l}\text { Formas tradicionais de produção e consumo de alimentos; Mudanças nas } \\
\text { formas de feitura das roças; Alimentos tradicionais; Trabalho coletivo }\end{array}$ \\
\hline $\begin{array}{l}\text { Práticas curativas } \\
\text { tradicionais do povo } \\
\text { Karajá Xambioá }\end{array}$ & $\begin{array}{l}\text { Plantas curativas; Religiosidade Karajá Xambioá; Organização social do } \\
\text { povo Karajá Xambioá; Medicina não indígena; Uso e consumo abusivo de } \\
\text { medicamentos não indígenas; Receitas de remédios tradicionais; Bulas de } \\
\text { remédios industrializados }\end{array}$ \\
\hline Lixo & $\begin{array}{l}\text { Impactos ambientais; Poluição; Degradação do lixo; Doenças causadas pelo } \\
\text { lixo nas aldeias; Manejo adequado do lixo: reciclagem; Mudanças nos } \\
\text { hábitos alimentares; Mudanças nas práticas culturais }\end{array}$ \\
\hline Cantos guarani & $\begin{array}{l}\text { Funções socioculturais da música Guarani; Cantos de alegria Guarani } \\
\text { Cantos de tristeza Guarani; Cantos Karajá }\end{array}$ \\
\hline $\begin{array}{l}\text { Terra e Território } \\
\text { Guarani }\end{array}$ & $\begin{array}{l}\text { Concepção Guarani de terra e território; Cosmologia Guarani; Êxodo } \\
\text { Guarani; Presença Guarani na Terra Indígena Xambioá }\end{array}$ \\
\hline Globalização & $\begin{array}{l}\text { Impactos dos processos de globalização para as populações indígenas } \\
\text { brasileiras; Interações entre diferentes comunidades ao redor do globo; meios } \\
\text { tecnológicos de comunicação e impactos positivos e negativos para as } \\
\text { populações indígenas brasileiras }\end{array}$ \\
\hline $\begin{array}{l}\text { Jogos e brincadeiras } \\
\text { Xambioá }\end{array}$ & $\begin{array}{l}\text { Funções de socialização de jogos e brincadeiras tradicionais do povo } \\
\text { Xambioá e seus vínculos com elementos culturais particulares. }\end{array}$ \\
\hline
\end{tabular}

Espaço Ameríndio, Porto Alegre, v. 7, n. 1, p. 95-145, jan./jun. 2013. 
ANDRÉ MARQUES DO NASCIMENTO - Desafios à elaboração curricular para a educação...

Quadro 1 - Temas contextuais trabalhados no Estágio Pedagógico pelo comitê Karajá Xambioá e Guarani.

Fonte: Cadernos de Estágio Pedagógico dos acadêmicos e acadêmicas indígenas Karajá Xambioá e Guarani.

A abordagem dos temas contextualizados de trabalho, cuja amostra é apresentada acima, representa, ainda, a meu ver, o reconhecimento e o enfrentamento da falácia do progresso técnicocientífico da modernidade ocidental capitalista, da qual a educação escolar foi um dos instrumentos mais eficazes e ao mesmo tempo cruéis por difundir a ideia de progresso para todos/as, engendrada por uma perspectiva eurocêntrica, exterminando qualquer compreensão ou negociação dos próprios sentidos de "desenvolvimento" e de "progresso" para diferentes povos e culturas e imputando aos/às excluídos/as a condição de subdesenvolvidos/as, atrasados/as, pobres e primitivos/as, para a qual a única forma de redenção seria a rendição, a resignação e a aceitação das condições da modernidade/colonialidade.

Quantas vezes nos perguntamos, por exemplo, o que significa "progresso" e "desenvolvimento" para os povos indígenas? Nesta direção, Romaine (2009) analisa como, na contemporaneidade,

embora a sabedoria convencional na qual a maioria das teorias de desenvolvimento é baseada frequentemente assuma que as pessoas e lugares são pobres porque não têm recursos, a pobreza é claramente um fenômeno complexo. Causa e efeito são muitas vezes confusos nos argumentos de que a pobreza é causada pela falta de infra-estrutura, serviços e oportunidades de emprego nas comunidades rurais onde a maioria dos povos indígenas vivem. Assim, as políticas predominantes em geral impuseram a assimilação e a integração aos modos de produção e emprego da sociedade dominante, muitas vezes necessitando de migração ou do deslocamento forçado para áreas urbanas. Tais estratégias são motivadas pela percepção equivocada e estereotipada em relação aos povos indígenas, de acordo com as quais seus modos de vida (particularmente dos caçadores-coletores) e as suas línguas seriam primitivas, atrasadas e um obstáculo para o desenvolvimento (ROMAINE, 2009, p. 56, tradução minha). 
ANDRÉ MARQUES DO NASCIMENTO - Desafios à elaboração curricular para a educação...

Ainda conforme a autora,

os medidores de bem-estar hegemônicos baseados principalmente em indicadores econômicos estão, portanto, frequentemente em desacordo com as percepções e os objetivos indígenas. [...] Ao focalizar apenas as lacunas entre as populações indígenas e as populações majoritárias hegemônicas em termos de medição econômica, outros fatores como a discriminação e a importância das percepções e prioridades indígenas são normalmente ignorados e/ou desprezados. As nações ricas continuam a estipular a agenda para o desenvolvimento, a definir seu escopo e a monitorar seu progresso em termos de indicadores quantitativos de desenvolvimento supostamente universais. Esta visão de mundo permeia o setor educativo, no qual o objetivo principal da educação é visto como um meio de desenvolvimento econômico, conduzido pela necessidade de mão de obra altamente treinada (ROMAINE, 2009, p. 57, tradução minha).

Como apresentado anteriormente, os conhecimentos e sua forma crítica de abordagem pelos professores e professoras indígenas karajá xambioá e guarani mostram claramente que suas concepções de "desenvolvimento" e de "progresso", se é que assim podem ser nomeadas, ao menos no que se refere ao contexto da educação escolar, caminham na direção contrária do que temos assistido no mundo moderno/colonial ocidental e, mais uma vez, ensinam a nós, não indígenas imbuídos/as pela lógica do pesamento ocidental de matriz eurocêntrica, que ainda temos muito, mas muito o que aprender com eles e elas, se almejamos perspectivas menos autodestrutivas de futuro.

\section{Referências bibliográficas}

ALBÓ, Xavier. Cultura, interculturalidade, inculturação. São Paulo: Edições Loyola, 2005.

ALMEIDA FILHO, Naomar. Transdisciplinaridade e o paradigma pós-disciplinar na saúde. Saúde e Sociedade, v. 14, n. 3, p. 30-50, set./dez., 2005. Disponível em: http://www.scielo.br/pdf/sausoc/v14n3/04.pdf. Acesso em: 15 jul 2012. 
ANDRÉ MARQUES DO NASCIMENTO - Desafios à elaboração curricular para a educação...

ASHCROFT, Bill; GRIFFITHS, Gareth; TIFFIN, Helen. The empire writes back: theory and practice in post-colonial literatures. London/New York: Routledge, 2002.

BRANDÃO, Carlos Antônio Leite. A transdisciplinaridade. In: PAULA, João Antônio. (Org.). A transdisciplinaridade e os desafios contemporâneos. Belo Horizonte: Editora UFMG, 2008. p. 16-39.

BRASIL. Constituição da República Federativa do Brasil: promulgada em 5 de outubro de 1988 - Contém as emendas constitucionais posteriores. Brasília: Senado, 1988.

CAPRA, Fritjof. Falando a linguagem da natureza: princípios da sustentabilidade. In: STONE, Michael K.; BARLOW, Zenobia. (Org.). Alfabetização ecológica: a educação das crianças para um mundo sustentável. São Paulo: Cultrix, 2006. p. 46-57.

COTRIM, Rodrigo Guimarães Prudente Marquez. Romwaihku Akwẽ-Xerente, Português, English: Diálogo Intercultural no Ensino-Aprendizagem do Inglês (L3) para professores indígenas. München: Lincom Academic Publishers, 2012.

CURARRÁ KARAJÁ, Augusto. Relatório de Estágio Pedagógico: Práticas Curativas do Povo Karajá Xambioá. Goiânia: Licenciatura Intercultural - UFG, 2011. Inédito.

CURARRÁ KARAJÁ, Augusto; LIMA KARAJÁ, Eva. Hábitos alimentares tradicionais do povo Karajá Xambioá. Trabalho de conclusão de curso. Goiânia: Licenciatura Intercultural para Formação Superior de Professores e Professoras Indígenas/UFG, 2012. Inédito.

CURARRÁ KARAJÁ, Augusto et al. Ixỹbiòwa Utura. In: NASCIMENTO, André Marques (Org.). Ixỹbiòwa Utura. Goiânia: CEGRAF, 2010.

GROSFOGUEL, Rámon. The epistemic decolonial turn: beyond political-economy paradigms. Cultural Studies, v. 21. n. 2-3, p. 211-223, mar./mai., 2007.

GUARANY SILVA, Edvan. Como o povo Guarani se espalhou no Brasil. Jornal Takinahakỹ, Ano III, n. 2, p. 15, jan/fev, 2011.

Hábitos alimentares do povo Guarany Mbyà. Trabalho de conclusão de curso. Goiânia: Licenciatura Intercultural para Formação Superior de Professores e Professoras Indígenas/UFG, 2013. Inédito.

IBGE - INSTITUTO BRASILEIRO DE GEOGRAFIA E ESTATÍSTICA. Indígenas. 2012. Disponível em: http://www.ibge.gov.br/indigenas/index.htm. Acesso em: 15 abr 2012.

ISA - INSTITUTO SOCIOAMBIENTAL. De olho nas Terras Indígenas do Brasil: Terra Indígena Xambioá. Disponível em: http://ti.socioambiental.org/\#!/terrasindigenas/3905. Acesso em: 15 abr 2012. 
ANDRÉ MARQUES DO NASCIMENTO - Desafios à elaboração curricular para a educação...

KRUMARE KARAJÁ, Mauro. Experiências no Estágio da Licenciatura Intercultural da Universidade Federal de Goiás. Goiânia: UFG 2012. Manuscrito Inédito.

KUMARE KARAJÁ, Paulo. A construção do projeto político-pedagógico. Goiânia: UFG, 2011a. Manuscrito Inédito.

Relatório da Atividade Extraescolar. In: WAJUREMA KARAJÁ et al. Revitalização do artesanato tradicional Karajá Xambioá. Trabalho de conclusão de curso. Goiânia: Licenciatura Intercultural para Formação Superior de Professores e Professoras Indígenas/UFG, 2011b.

Experiências no Estágio da Licenciatura Intercultural da UFG nas escolas do povo Xambioá. Goiânia: UFG, 2012. Manuscrito Inédito.

KURIKAlá KARAJÁ, Luiz Pereira. Preservação do conhecimento Karajá Xambioá e o diálogo com o conhecimento não-indígena: experiências de Estágio Pedagógico da Licenciatura Intercultural da UFG. Goiânia: UFG, 2012. Manuscrito inédito.

LADEIRA, Maria Inês. Mbya. In: ISA - Instituto Socioambiental. Povos Indígenas no Brasil, 2003. Disponível em: http://pib.socioambiental.org/pt/povo/guarani-mbya/. Acesso em: 15 abr 2012.

LIMA GUARANI, Indionor Pereira. Relatório de Atividade Extraescolar. In: WAJUREMA KARAJÁ, Albertino et al. Revitalização do artesanato tradicional Karajá Xambioá. Trabalho de conclusão de curso. Goiânia: Licenciatura Intercultural para Formação Superior de Professores e Professoras Indígenas/UFG, 2011.

Experiências de Estágio na Licenciatura Intercultural da UFG e novas concepções educacionais. Goiânia: UFG, 2012. Manuscrito inédito.

LIMA KARAJÁ, Eva. Relatório de Estágio Pedagógico: Hábitos Alimentares do Povo Karajá Xambioá. Goiânia: Licenciatura Intercultural - UFG, 2010. Inédito.

Relatório de Estágio Pedagógico: Lixo na Terra Indígena Xambioá. Goiânia: Licenciatura Intercultural - UFG, 2011. Inédito.

MELLO, Maria F.; BARROS, Vitória Mendonça; SOMMERMAN, Américo. Introdução. In: Educação e transdisciplinaridade II. São Paulo: TRIOM, 2002. p. 0926.

NASCIMENTO, André Marques. Português Intercultural: fundamentos para a educação linguística de professores e professoras indígenas em formação superior específica numa perspectiva intercultural. München: Lincom Academic Publishers, 2012.

NICOLESCU, Basarab. O manifesto da transdisciplinaridade. São Paulo: Triom, 
ANDRÉ MARQUES DO NASCIMENTO - Desafios à elaboração curricular para a educação...

2005.

ORR, David. W. Lugar e Pedagogia. In: STONE, Michael K.; BARLOW, Zenobia. (Org.). Alfabetização ecológica: a educação das crianças para um mundo sustentável. São Paulo: Cultrix, 2006. p. 114-124.

RODRIGUES, Patrícia Mendonça. A caminhada de Tanỹxiwè: uma teoria Javaé da história. Tese de Doutorado. Chigaco/Illinois: Universidade de Chicago, 2008.

ROMAINE, Susan. Linguistic diversity and poverty: many languages and poor people in a globalizing world. In: WEI, Li; COOK, Vivian (Org.). Contemporary Applied Linguistics: Volume 2 - Linguistics for the Real World. London/New York: Continuum, 2009. p. 46-64.

SANTOS, Boaventura de Souza. Um discurso sobre as Ciências na transição para uma ciência pós-moderna. Estudos Avançados, São Paulo, v. 2, n. 2, p. 46-71, 1988.

2008.

A gramática do tempo: para uma nova cultura política. São Paulo: Cortez,

SOMMERMAN, Américo. Inter ou transdisciplinaridade?: da fragmentação disciplinar ao novo diálogo entre os saberes. São Paulo: Paulus, 2006.

TORAL, André. Cosmologia e sociedade Karajá. 1992. 280 f. Dissertação (Mestrado em Antropologia Social) - UFRJ/Rio de Janeiro: Museu Nacional/UFRJ, [1992].

Karajá do Norte. In: Instituto Socioambiental. Povos Indígenas no Brasil. 2001. Disponível em: http://pib.socioambiental.org/pt/povo/karaja-do-norte. Acesso em: 15 abr 2012.

TUBINO, Fidel. Del interculturalismo funcional al interculturalismo crítico. In: SAMANIEGO, M.; GARBARINI, C. G. (Org.). Rostros y fronteras de la identidad. Temuco: Universidad Católica de Temuco, 2004. p.151-164. Disponível em: http://www.pucp.edu.pe/ridei/pdfs/inter_funcional.pdf. Acesso em: 15 mar 2010.

TXEBUARÈ KARAJÁ, Viviane. Artesanato feminino do povo Xambioá: Ritxoko. Trabalho de conclusão de curso. Goiânia: Licenciatura Intercultural para Formação Superior de Professores e Professoras Indígenas/UFG, 2013. Inédito.

WAJUREMA KARAJÁ, Albertino. Relatório de Atividade Extraescolar. In: WAJUREMA KARAJÁ, Albertino et al. Revitalização do artesanato tradicional Karajá Xambioá. Trabalho de conclusão de curso. Goiânia: Licenciatura Intercultural para Formação Superior de Professores e Professoras Indígenas/UFG, 2011.

Práticas didático-pedagógicas do Estágio da Licenciatura Intercultural da UFG. Goiânia: UFG, 2012. Manuscrito inédito.

WAJUREMA KARAJÁ, Albertino et al. Revitalização do artesanato tradicional 
ANDRÉ MARQUES DO NASCIMENTO - Desafios à elaboração curricular para a educação...

Karajá Xambioá. Trabalho de conclusão de curso. Goiânia: Licenciatura Intercultural para Formação Superior de Professores e Professoras Indígenas/UFG, 2011. 